University of Louisville

ThinkIR: The University of Louisville's Institutional Repository

\title{
Synthesis of a nanoscale gold-coated, thermoresponsive molecular release system.
}

Ryan C. Weegens

University of Louisville

Follow this and additional works at: https://ir.library.louisville.edu/honors

Part of the Nanomedicine Commons, and the Other Chemicals and Drugs Commons

\section{Recommended Citation}

Weegens, Ryan C., "Synthesis of a nanoscale gold-coated, thermoresponsive molecular release system." (2017). College of Arts \& Sciences Senior Honors Theses. Paper 139.

http://doi.org/10.18297/honors/139

This Senior Honors Thesis is brought to you for free and open access by the College of Arts \& Sciences at ThinkIR: The University of Louisville's Institutional Repository. It has been accepted for inclusion in College of Arts \& Sciences Senior Honors Theses by an authorized administrator of ThinkIR: The University of Louisville's Institutional Repository. This title appears here courtesy of the author, who has retained all other copyrights. For more information, please contact thinkir@louisville.edu. 


\title{
Synthesis of a Nanoscale Gold-Coated, Thermoresponsive Molecular Release System
}

\author{
Authored by \\ Ryan C. Weegens \\ Department of Chemistry \\ University of Louisville, KY
}

A Dissertation Submitted in Partial Fulfillment of the Requirements for Graduation summa cum laude

With a Bachelor's degree in Biology and Chemistry

University of Louisville

Honors Scholars Program

March 21, 2017 


\section{Table of Contents}

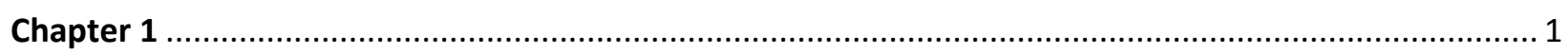

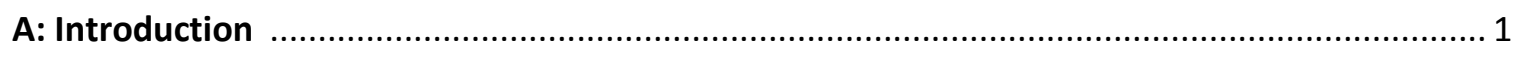

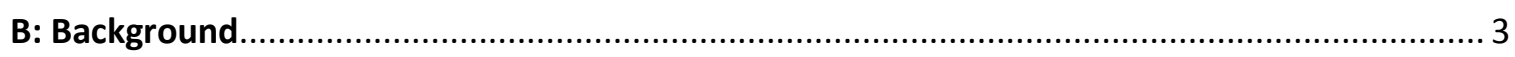

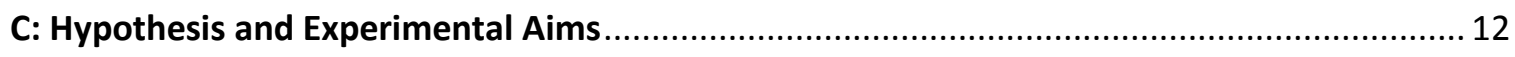

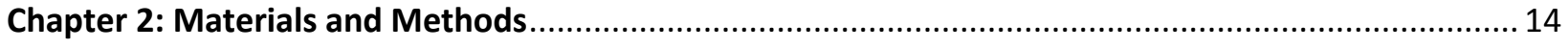

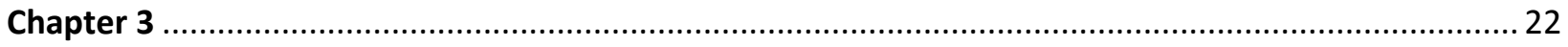

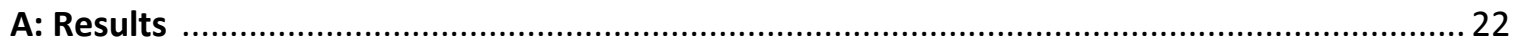

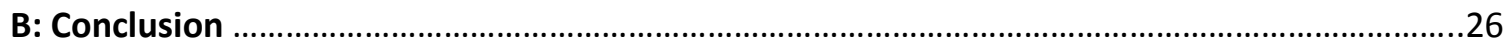

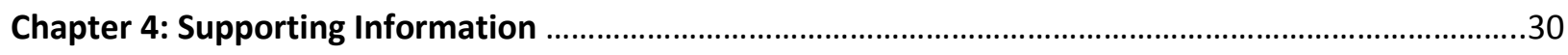




\section{Figures}

FIGURE

PAGE

1 Egyptian relief depicting the process of collecting honey as a "beekeeper." 1

2 Dox derivatization by hydrazine reagent to afford a Dox-hydrazone. 4

3 Cyclization substrates examined by Knipp et al. ${ }^{3} \quad 5$

4 Intramolecular cyclization upon heating. 5

5 Linker-NP heating via AMF for payload release. 7

6 PANC-1 cells exposed to 0,25 , and $50 \mu \mathrm{g} / \mathrm{mL}$ dose of nanoparticles, respectively, without laser irradiation $(\mathbf{A}-\mathbf{C})$ and with laser irradiation at $\quad 8$ $7.9 \mathrm{~W} / \mathrm{cm}^{2}$ power density (D-F). ${ }^{8}$

7 Summary of experimental linker system. 9

8 Overview of the experiment clarifying my project as the control group. $\quad 10$

9 Summary of amine-based linker system. 13

10 Summary of amine-deficient linker system. 13

11 Setup of the AMF studies. 20

12 The alcohol fragment which indicates release of payload. 22

13 Oxime ether reduction product. 24

14 Graphical representation of the percent release of the amine-based linker 27 $\begin{array}{ll}\text { system vs. the amine-deficient linker system. } & 27 \\ \text { IR spectrum of product } 2 . & 31\end{array}$

$\begin{array}{lll}15 & \text { IR spectrum of product } 2 . & 31 \\ 16 & \text { IR spectrum of product } 3\end{array}$

17 IR spectrum of product 4. 33

18 IR spectrum of product 5.

19 IR spectrum of product 6.

$20{ }^{1} \mathrm{H}$ NMR spectrum of product 2 . 36

$21{ }^{1} \mathrm{H}$ NMR spectrum of product 3.

$22{ }^{1} \mathrm{H}$ NMR spectrum of product 4. 38

$23{ }^{1} \mathrm{H}$ NMR spectrum of product 5.

$24{ }^{1} \mathrm{H}$ NMR spectrum of product 6.

$25{ }^{13} \mathrm{C}$ NMR spectrum of product 2 . 41

$26{ }^{13} \mathrm{C}$ NMR spectrum of product 3. 42

$27{ }^{13} \mathrm{C}$ NMR spectrum of product 4.

$28{ }^{13}$ C NMR spectrum of product 5.

$29{ }^{13} \mathrm{C}$ NMR spectrum of product 6. 


\section{Acknowledgements}

I would like to take a few lines to express gratitude to some people. I'd like to start by thanking Dr. Michael Nantz from the Department of Chemistry at the University of Louisville. I don't know if you knew how clueless and clumsy I was when you agreed to have me in your research lab, but I am extremely grateful for the huge risk you took by investing in me these past two years. I have grown under your teaching and guidance as you have invested in my growth as a student, chemist, and a young man. You always know the right thing to say at the right time. Thank you.

Next, I'd like to thank Dr. Christine Rich. Your office was always open whenever I had questions or needed to vent about my struggles with "p-chem." You kept me on track to make sure that I was doing what I needed to get my degree. Most importantly, you have shown us chemistry students that the chemistry department truly cares about us and wants us to succeed. You and the rest of the PRIMES faculty challenged me to grow myself as a chemist and student by giving me the opportunity to work as a UTA. I will not soon forget your passion for us chemistry students. Thank you.

I'd also like to thank Sara Biladeau, the graduate student with whom I spent many hours working over the past 2 years. You are a real-life MacGyver. You taught me how to make the most unseemly contraptions in order to get the job done. From the many laughs, failures, and successes, I know that I could not have asked for a better research partner. Thank you. 
Thank you to my family and friends who supported me while I spent countless hours, days, or sometimes weeks without seeing them. Lastly, I thank my dog, Riley, who pretends to be listening when I bounce ideas off of him. 


\begin{abstract}
The work presented here was performed in conjunction with an experimental group in order to prove the concept that an alternating magnetic field (AMF) could be used to induce an intramolecular cyclization to effect payload release. The system studied here consisted of a fluorophore tethered to gold-coated iron oxide nanoparticles $\left(\mathrm{Fe}_{3} \mathrm{O}_{4} \mathrm{NPs}\right)$ via an organic linker consisting of 2 key elements: a carbonate (electrophile) and an amine (nucleophile). Connected to the carbonate was the fluorophore, anthracene, which was attached to the organic linker system by means of an oxime ether linkage. This thesis work served as the control group for the study by examining the absence of the amine. The control linker system was synthesized over 5 steps with a $53 \%$ overall yield. The amine-deficient control system, containing a thiol and carbonate group, was then covalently bound to gold-coated $\mathrm{Fe}_{3} \mathrm{O}_{4} \mathrm{NPs}$. The system was then subjected to an alternating magnetic field to promote local hyperthermia which would drive payload release for the experimental group but not for the control group due to the lack of a nucleophilic element. The control system was subjected to the AMF and analytical methods were performed on the supernatant of the solution by matrix-assisted laser desorption/ionization time of flight (MALDI-TOF). Results concluded that the control system withstood AMF exposure and retained its payload. Further studies were performed using lithium aluminum hydride (LAH) and dithiothreitol (DTT) on the control system in order to prove that the payload was indeed present on the system. Comparing the results obtained on the control system with that of the experimental system, intramolecular cyclization is proven to be the preferred mechanism of payload release.
\end{abstract}




\section{Lay Summary}

In this work, the control group of a gold nanoparticle-bound molecular delivery system was designed and tested. The purpose of this work was to prove that a payload is released by a specific mechanism. The control system was designed by removing one vital atom responsible for an important role in the mechanism. With this one atom missing, the payload would be unable to release, thus proving that release likely occurs by this proposed cyclization mechanism. After testing the control system, it was discovered that no payload had released, thus supporting the proposed mechanism. Additional testing was performed in order to prove that the payload was indeed attached to the control system. With this evidence in hand, we conclude that the molecular release system occurs by the cyclization mechanism that was hypothesized. 


\section{Chapter 1}

\section{Part A: Introduction}

The utilization of natural compounds for the treatment of diseases dates back

thousands of years. One of the oldest known medical texts, the Ebers Medical Papyrus from ancient Egypt, suggests using honey (Figure 1) to treat infections and a mixture of berries from the castor oil tree, Gengent beans, and Male Palm to cure constipation. ${ }^{1}$

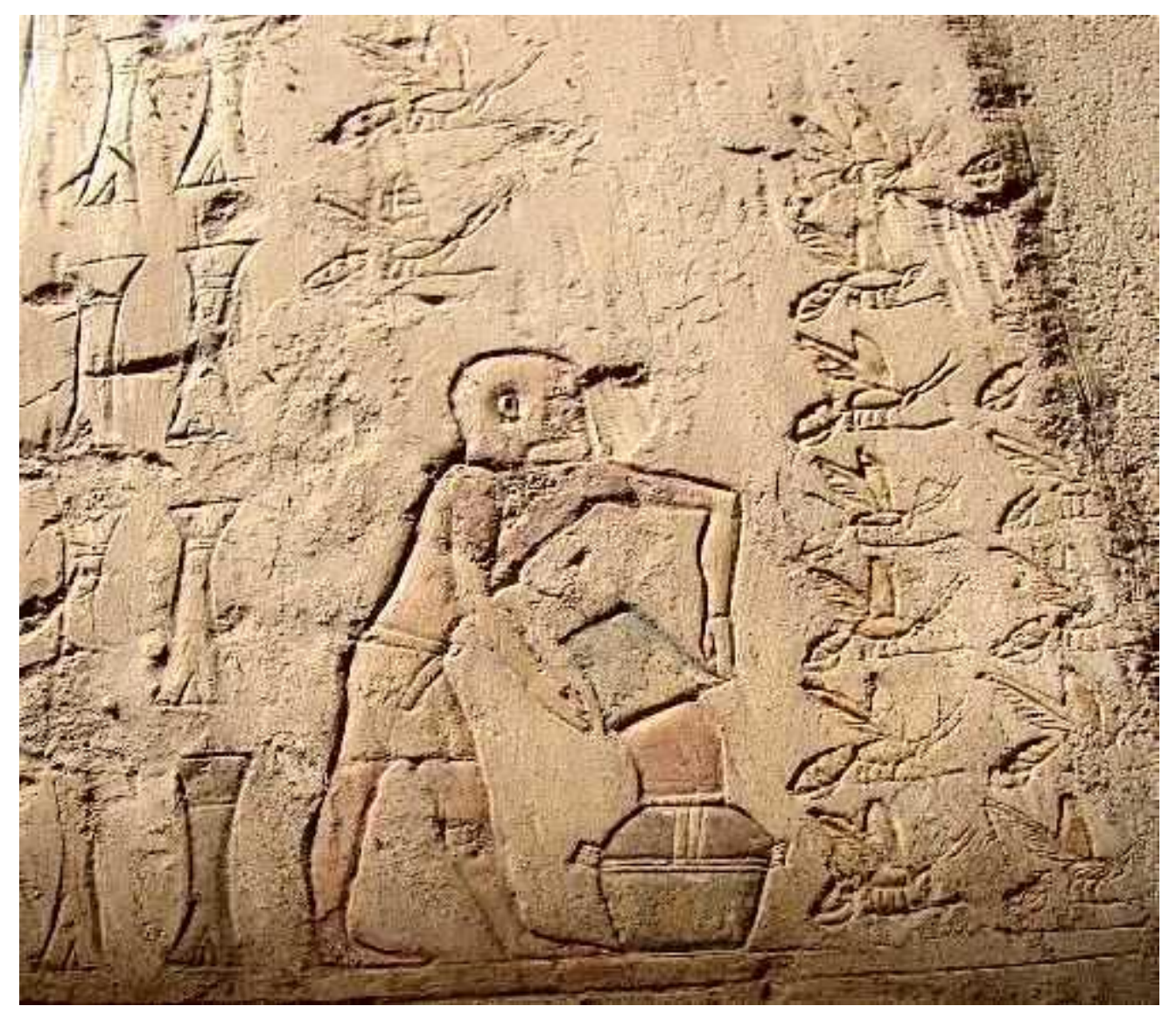

Figure 1. Egyptian relief depicting the process of collecting honey as a "beekeeper." Honey was a large part of Egyptian culture used in many parts of daily life, such as cooking and medicinal practices. 
Without knowledge of the chemical or molecular identities of the active ingredients, the Egyptians used dozens of plants for medicinal actions, building a foundation for what would become the beginning of pharmacology. Later in history, as scientists theorized that medicinal outcomes were the result of molecular interactions at the cellular level, a more modern form of pharmacology flourished. Instead of investigating crude extracts, an emphasis was placed on the effects of pure compounds at both the cellular and organ system level, giving rise to drugs such as morphine. Coupled with the field of organic chemistry, many natural products from biological sources have been successfully synthesized and incorporated into modern medicine. However, while these medicines can be beneficial, they can also have devastating effects at high concentrations in the body. Often the danger is related to a compound's effect on a specific organ, such as with cardiotoxicity, for example. While a drug may aid one system, it can be detrimental to others. These dangers are what have encouraged the development of methods for drug delivery, which generally utilize a controlled-release mechanism to ensure drug release at a target site. Delivery systems allow administration of compounds with the options of selecting how much, where, and even when a drug will become active, thus reducing the harm associated with a systemically circulating drug. 


\section{Part B: Background}

Stimuli-Responsive Linkers. Mimicking the function of transport proteins to aid in trafficking hormones so as to mitigate their premature metabolism, the covalent attachment of a molecular payload, such as a drug, to nanoparticles can similarly resolve the problem of premature release (i.e., leeching). Covalent attachment can also render the payload pharmaceutically inactive until release occurs. A stimulus, ideally one that can be triggered, generally is required to cleave the covalent linkage for payload release to occur. Such a stimulus can be external to the targeted treatment site to afford both spatial and temporal control over release - this is highly desired. Most common, however, is use of an internal stimulus, such as a change in $\mathrm{pH}$. With the slightly acidic exterior environment of a cancerous cell (pH 5.0) compared to the physiological environment of healthy cells ( $\mathrm{pH} 7.4$ ), a decrease in $\mathrm{pH}$ is just one avenue by which a change in the chemical environment can be used as a release stimulus. For example, Aryal et al. ${ }^{2}$ demonstrated that an acidic environment promoted the cleavage (i.e., hydrolysis) of a hydrazone linkage formed by reaction of a hydrazine-functionalized linker motif with the $C(13)$ ketone moiety in doxorubicin (Dox) (Figure 2). The authors also noted, however, that the drug Dox was slowly released even without an acid environment, at physiological pH (i.e., leeching occurred). These findings illustrate the unpredictability of a dynamic chemical environment and the challenges associated with designing a release trigger. 


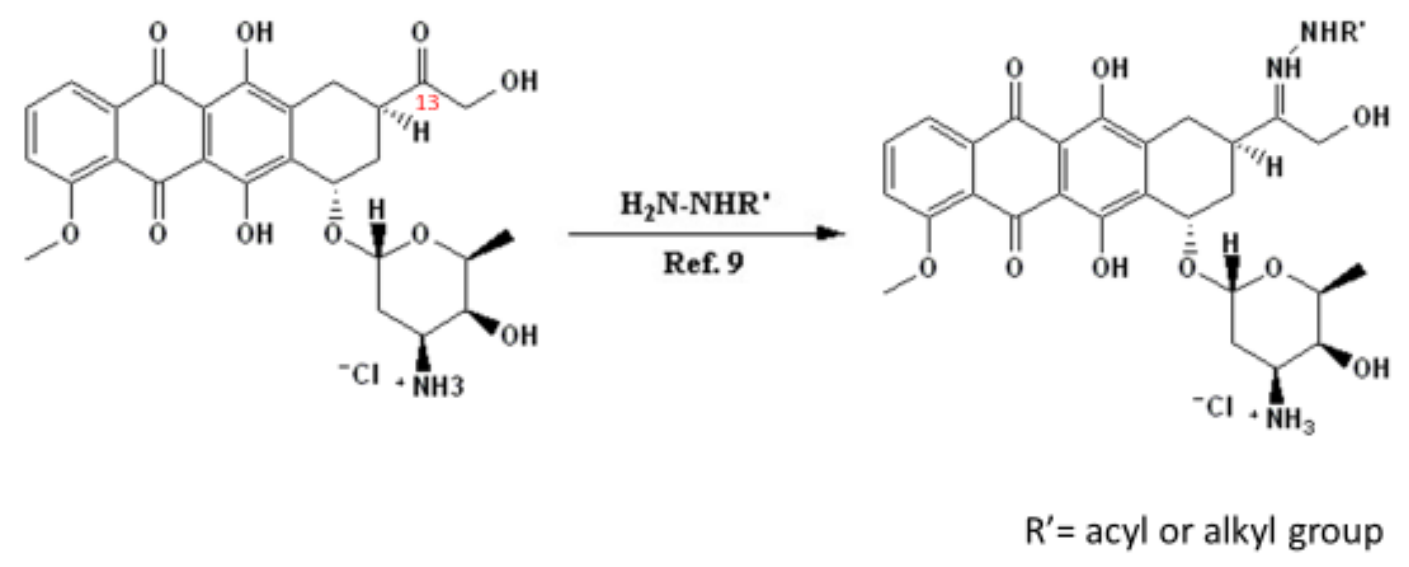

Figure 2. Dox derivatization by hydrazine reagent to afford a Dox-hydrazone

Payload Release Caused by Thermally-Induced Cyclization. Knipp et al. ${ }^{3}$ explored development of a substrate release mechanism that relies on a thermally-induced intramolecular cyclization as the trigger for payload release. The system was designed for use within a poly(dimethylsiloxane) microchannel. Several substrates that differed in linker length and functionality were tested for heat-induced intramolecular cyclization (Figure 3). The studies revealed that ester and carbonate moieties cyclized much more efficiently with mild heating (Figure 3). Upon testing for the optimal ring size for cyclization, Knipp et al. determined that the 5- and 6- member rings released a greater proportion of payload when heated at $55^{\circ} \mathrm{C}$ as compared to the 7-member ring system. The carbonate moiety (Figure 3, structure 2) that formed a 5-member ring upon cyclization was chosen for microchannel demonstrations. 
<smiles>C=CCNCCNCC1CCCC1C(=O)OCC</smiles>

$1 n=1-3$<smiles>C=CCNCC1CCCC1OC(=O)OCC</smiles>

$2 n=1-2$<smiles>C=CCNCCNC(=O)OCC</smiles>

3<smiles>C=CCNCCCC(=O)NCC</smiles>

4<smiles>[Y]CC(C)(C)CCN(P)CC=C</smiles>

$$
\begin{aligned}
& 5,6 \mathrm{Y}=\mathrm{CH}_{2} \text { or } \mathrm{O}, \mathrm{R}=\mathrm{H} \\
& \mathrm{R}^{\prime}=\text { 2-(9-anthracenyl)ethyl }
\end{aligned}
$$

Figure 3. Cyclization substrates examined by Knipp et al. ${ }^{3}$

1-6

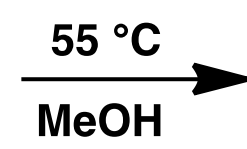<smiles>[R]C1([R])CN(CC=C)C(=O)[Y]([H])([H])C1</smiles><smiles>[X]CCc1c2ccccc2cc2ccccc12</smiles>

$$
\begin{aligned}
& \mathrm{Y}=\mathrm{CH}_{2} \text { or } \mathrm{O} \\
& \mathrm{R}=\mathrm{H} \text { or } \mathrm{CH}_{3}
\end{aligned}
$$

Figure 4. Intramolecular Cyclization upon heating.

Thermally Reactive Linker for $\mathrm{Fe}_{3} \mathrm{O}_{4}$-Silica Core-Shell NPs. Knipp et al. applied the thermoresponsive linker concept to nanoparticles (NPs) using an $\mathrm{Fe}_{3} \mathrm{O}_{4}$-silica core-shell system. ${ }^{3}$ A fluorophore was used as the payload for this experiment. As desired, the fluorophore was 
released as a result of an intramolecular cyclization of the linker upon exposure to an alternating magnetic field (AMF). As a result of the AMF, the magnetic moments of the NPS rapidly change, resulting in a phenomenon called Neel relaxation. Additionally, under the influence of the AMF, the NPs create friction with the medium as they physically rotate in conjunction with the rapidly changing magnetic field, a phenomenon known as Brownian relaxation. ${ }^{4}$ The combination of these two phenomena creates the local hyperthermia which distributes into the medium so as to heat the bulk solution. In this experiment, the AMF induces heating of the magnetic core of the nanoparticle system, which in turn powers re-cyclization by providing the necessary energy required to overcome the activation energy associated with the intramolecular attack.

In order to prove the veracity of the cyclization mechanism of release, a similar experiment was conducted implementing a Boc-protected amine, which prevents intramolecular cyclization of the amine. However, even with the Boc-protecting group, the fluorophore was still released, albeit at a slower rate than with the free amine. The authors attributed this leeching to the Lewis acidity of the silica shell functioning to catalyze carbamate hydrolysis on heating. The authors then sought to exploit this observation by designing a carbamate-based linker devoid of the amine (Figure 5). 


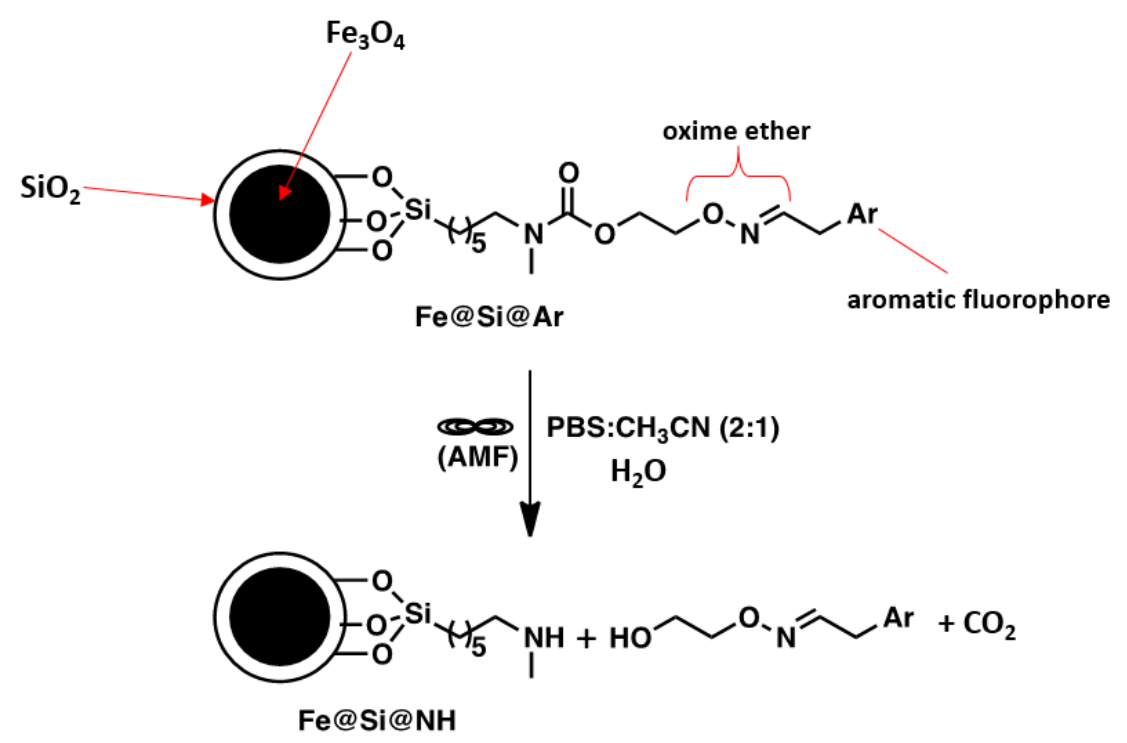

Figure 5. Linker-NP heating via AMF for payload release, $\mathrm{Ar}=$ anthracene

To allow for a simpler conjugation of the fluorophore to the linker, oxime ether formation between a linker-bound aminooxy moiety and an aldehyde moiety on the fluorophore was explored. This adjustment appeared to resolve the premature release of the fluorophore. However, at $37^{\circ} \mathrm{C}$ a trace amount of payload release did occur without AMF exposure. Given that gold is appreciably well tolerated by the body, and that gold is more inert than a silica coating as well as more readily functionalized, the present thesis work seeks to explore the use of gold-coated iron oxide NPs as the core of a triggerable delivery system.

$\mathrm{Fe}_{3} \mathrm{O}_{4}$-Gold Core Shell Nanoparticles. Gold NP systems have been utilized as drug delivery systems, as well as in delivery applications involving AMF exposure, due largely to their biocompatible properties. ${ }^{5}$ Unlike iron oxide particles, gold is not superparamagnetic; however, it can absorb ${ }^{6}$ and scatter ${ }^{7}$ laser radiation in the near-IR region as a result of surface plasmon resonance (SPR). Guo et al. synthesized $\mathrm{Fe}_{3} \mathrm{O}_{4}-\mathrm{Au}$ core-shell NPs for photothermal ablation of 
pancreatic cells using laser irradiation, ${ }^{8}$ and Mohammad et al. synthesized $\mathrm{Fe}_{3} \mathrm{O}_{4}$-Au core-shell NPs with a cysteine coating to deliver Dox to breast cancer cells in vitro. ${ }^{9}$
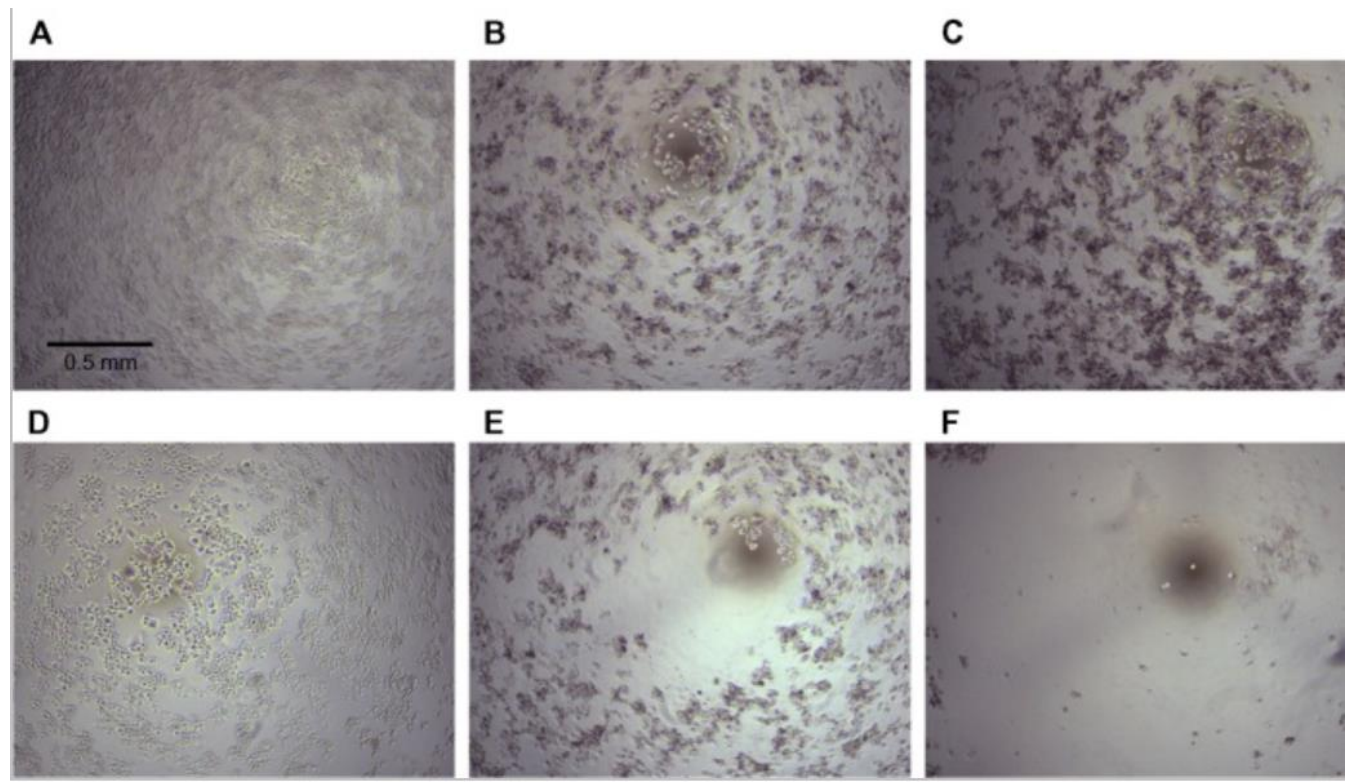

$\mathrm{F}$

Figure 6. PANC-1 cells exposed to 0,25 , and $50 \mu \mathrm{g} / \mathrm{mL}$ dose of nanoparticles, respectively, without laser irradiation $(\mathbf{A}-\mathbf{C})$ and with laser irradiation at $7.9 \mathrm{~W} / \mathrm{cm}^{2}$ power density $(\mathbf{D}-\mathbf{F}){ }^{8}$

Figure 6 above shows the results of Guo et al.'s experiment which used laser irradiation and $\mathrm{Fe}_{3} \mathrm{O}_{4}$-Au core-shell NPs to destroy PANC-1 cancer cells. Row A-C received $\mathrm{Fe}_{3} \mathrm{O}_{4}$-Au coreshell NPs in concentrations of 0,25 , and $50 \mu \mathrm{g} / \mathrm{mL}$ respectively without laser irradiation. Row DF received $\mathrm{Fe}_{3} \mathrm{O}_{4}$-Au core-shell NPs in the same respective concentrations with a laser irradiation treatment that lasted 5 minutes. The treatment group of cells that received laser irradiation showed significantly decreased cell proliferation. This experiment demonstrated the efficacy of utilizing $\mathrm{Fe}_{3} \mathrm{O}_{4}$-Au core-shell NPs. ${ }^{8}$ 
As a means to overcome the challenge of non-triggered payload release, we will covalently attach the payload to a linker system that in turn is bound to a NP. The linker will cyclize to release the payload on exposure (external) to an AMF.

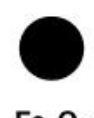

$\mathrm{Fe}_{3} \mathrm{O}_{4}$

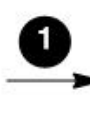

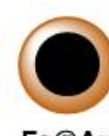

$\mathrm{Fe} @ \mathrm{Au}$

$\left(\mathrm{Fe}=\mathrm{Fe}_{3} \mathrm{O}_{4}\right)$

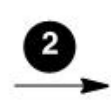

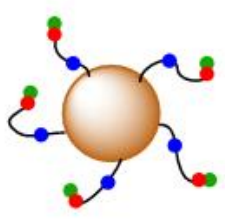

Fe@Au@LS

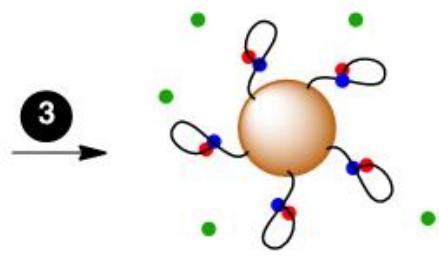

(LS = linker system)

payload (initially a fluorophore, ultimately derivatized Dox)

- carbonyl functionality

- nucleophilic element (initially an amino group)

Figure 7. Summary of nucleophilic linker system.

Using Figure 7 above as a visual summary, the complete idea of the experiment can be understood. Step 1 involves coating $\mathrm{Fe}_{3} \mathrm{O}_{4} \mathrm{NPs}$ with gold acetate, generating gold-coated $\mathrm{Fe}_{3} \mathrm{O}_{4}$ NPs. In Step 2, the gold-coated $\mathrm{Fe}_{3} \mathrm{O}_{4}$ NPs will be coated with an amine-based linker system using well-established thiol-gold monolayer formation. ${ }^{10}$ The amine-based linker system is comprised of three important parts: 1.) the nucleophilic element, the amine; 2.) a carbonate, which provides carbonyl functionality; and 3.) a payload, initially a fluorophore, ultimately a pharmaceutical such as Doxorubicin. For Step 3, the entire system will be subjected to an AMF 
to ultimately promote release of the payload by an intramolecular cyclization mechanism. Analytical processes will then be performed on the supernatant to confirm release of the payload. ${ }^{11}$

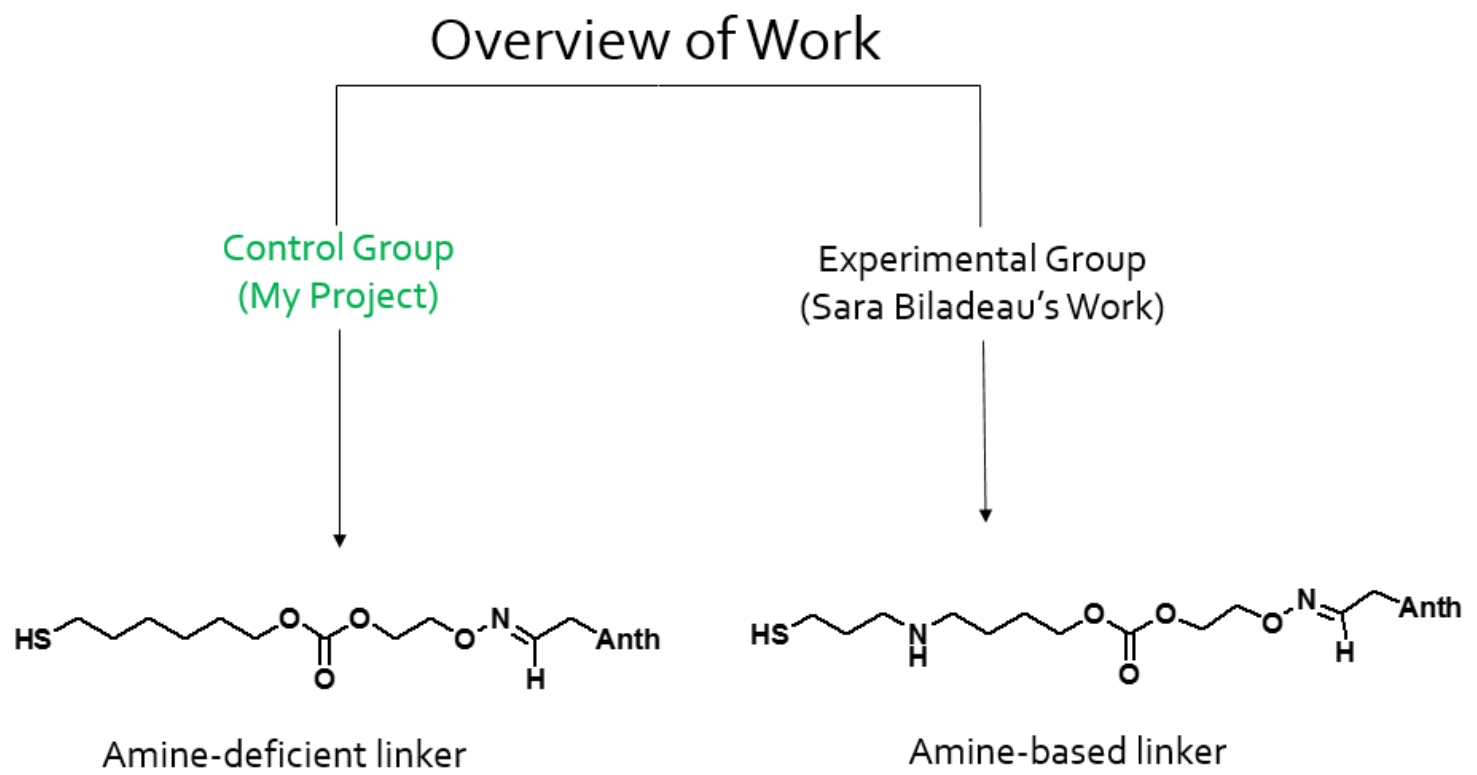

Figure 8: Overview of the experiment clarifying my project as the control group.

Figure 8 above is a visual representation of the experiment. As in any scientific research, both an experimental group and a control group must be designed and tested in order to validate a hypothesis. For this specific experiment, the experimental group will consist of Sara Biladeau's work with her amine-based linker system. This linker system contains the appropriate pieces necessary for payload release due to intramolecular cyclization. Furthermore, the control group consists of my work with the amine-deficient linker system. I designed my linker system to be almost identical to the amine-based linker system in all areas except one-the nucleophilic amine. By removing the nucleophilic amine portion from the linker system, my linker system would lack the ability to undergo an intramolecular cyclization and result in payload retention, 
supporting my hypothesis that the mechanism of payload release is by means of an intramolecular cyclization mechanism. 


\section{Part C: Hypothesis and Experimental Aims}

\section{Key Objective}

To confirm that the $2^{\circ}$-amine component of the linker system is essential for AMFtriggered release of the payload. The amine is believed to react with the proximal carbonate group given sufficient heat generated on AMF exposure, resulting in payload release. Its absence would obviate payload release via cyclization, the key mechanistic trigger believed necessary for payload release.

\section{Hypothesis}

Removal of the amine from the linker system will result in retention of the payload, even on exposure to AMF. Without the ability to cyclize, the carbonate group will not react to release the payload.

\section{Experimental Aims}

A. Synthesize a control linker system devoid of amine functionality and containing a fluorophore (anthracene) to evaluate payload release.

B. Load the linker system onto $\mathrm{Fe}_{3} \mathrm{O}_{4}$-gold core-shell nanoparticles.

C. After subjecting the nanoparticle-bound linker system to an alternating magnetic field as a means of analysis, evaluate payload release using MALDI-TOF. 

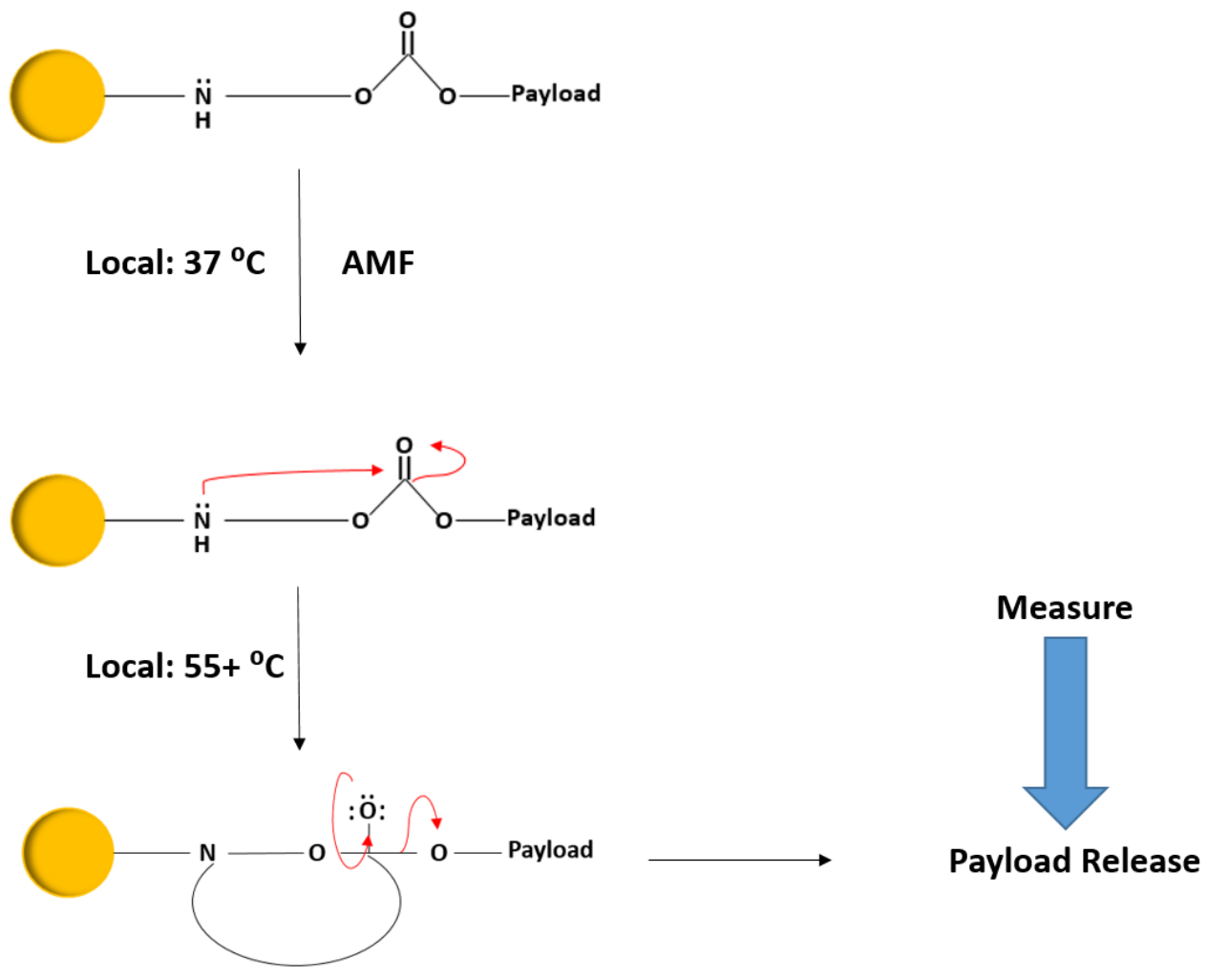

Figure 9. Summary of nucleophilic linker system.
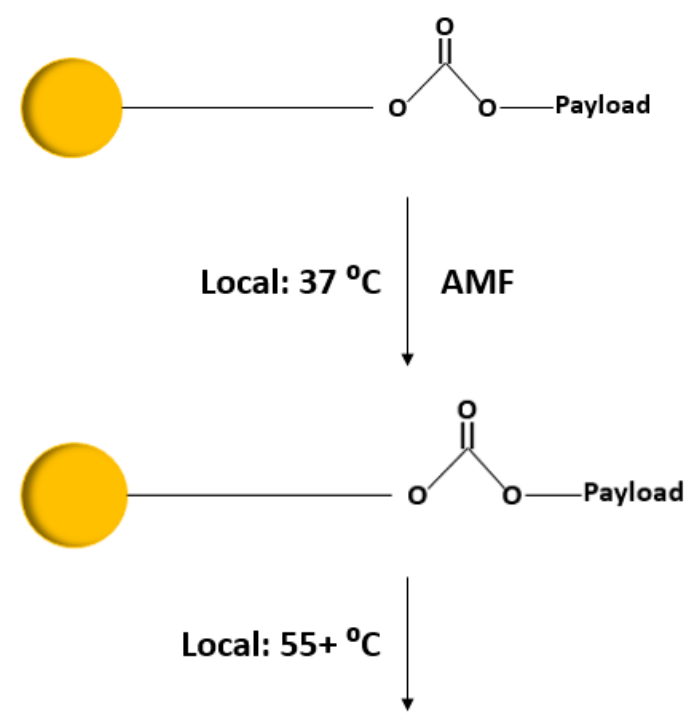

No Payload Release

Measure

Figure 10. PRESENT THESIS WORK: Summary of control, amine-deficient linker system. 


\section{Chapter 2}

\section{Materials and Methods}

The following procedures included below were used to synthesize the amine-deficient linker system. As a means of characterization of each step, the following spectroscopic techniques were utilized: Infrared spectroscopy (IR), proton nuclear magnetic resonance spectroscopy $\left({ }^{1} \mathrm{H}\right.$ NMR), carbon-13 nuclear magnetic resonance spectroscopy $\left({ }^{13} \mathrm{C} N M R\right)$, and high-resolution mass spectrometry (HRMS). For IR, significant peaks representing functional groups present on the molecule were recorded in $\mathrm{cm}^{-1}$. For ${ }^{1} \mathrm{H}$ and ${ }^{13} \mathrm{C} \mathrm{NMR}$, important peaks were recorded in parts per million (ppm). For HRMS, findings were recorded as a unit of mass per charge $(\mathrm{m} / \mathrm{z})$. The appropriate spectrum representing the specific spectroscopic method for each molecule can be found in Chapter 4 matched with its corresponding figure number.

\section{Synthesis of an Amine-free Linker System}

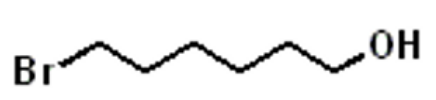

1
Triphenylmethanethiol

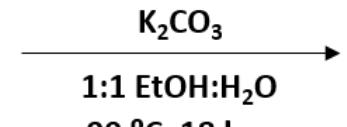

$90^{\circ} \mathrm{C}, 18 \mathrm{hrs}$.

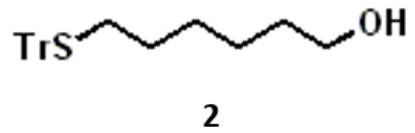

2

6-(Tritylthio)hexan-1-ol (2). 6-bromohexanol (0.526 g, $2.90 \mathrm{mmol}$ ) and triphenylmethanethiol $(0.802 \mathrm{~g}, 2.90 \mathrm{mmol})$ were added to a solution of $\mathrm{K}_{2} \mathrm{CO}_{3}(0.802 \mathrm{~g}, 5.80 \mathrm{mmol})$ in a 1:1 mixture of ethanol:water $(15.0 \mathrm{~mL})$ at $90{ }^{\circ} \mathrm{C}$. The mixture was stirred for 18 hours. On cooling, the reaction was quenched by addition of $1 \mathrm{M} \mathrm{HCl}$ and extracted with dichloromethane $(25 \mathrm{~mL} \times 3)$. The combined organic layer was washed with water $(25 \mathrm{~mL})$ and brine $(25 \mathrm{~mL})$, dried over anhydrous sodium sulfate, filtered, and concentrated by rotary evaporation to give $\mathbf{2}$ as a 
yellow oil ( $0.88 \mathrm{~g}, 82 \%$ yield) which was used in the next step without further purification.

Figure 15. IR v $\left(\mathrm{cm}^{-1}\right)$ 3341, 1488, 1442; Figure 20. $\left.{ }^{1} \mathrm{H} \mathrm{NMR} \mathrm{(500} \mathrm{MHz,} \mathrm{CDCl}_{3}\right): \delta 1.24$ (quint, $J=$ $8.5 \mathrm{~Hz}, 5 \mathrm{H}$ ), 1.39 (pent, $J=7.0 \mathrm{~Hz}, 2 \mathrm{H}$ ), 1.48 (pent, $J=6.5 \mathrm{~Hz}, 2 \mathrm{H}), 2.14(\mathrm{t}, J=7.5 \mathrm{~Hz}, 2 \mathrm{H}), 3.58(\mathrm{t}$, $J=6.5 \mathrm{~Hz}, 2 \mathrm{H}), 7.19(\mathrm{t}, J=7.5 \mathrm{~Hz}, 3 \mathrm{H}), 7.27(\mathrm{t}, J=7.5 \mathrm{~Hz}, 6 \mathrm{H}), 7.41(\mathrm{~d}, J=8.5 \mathrm{~Hz}, 6 \mathrm{H})$; Figure 25 . ${ }^{13} \mathrm{C}$ NMR $\left(400 \mathrm{MHz}, \mathrm{CDCl}_{3}\right): 825.5,28.7,28.9,32.1,32.7,63.1,66.6,126.7,128.1,129.8,145.4$.

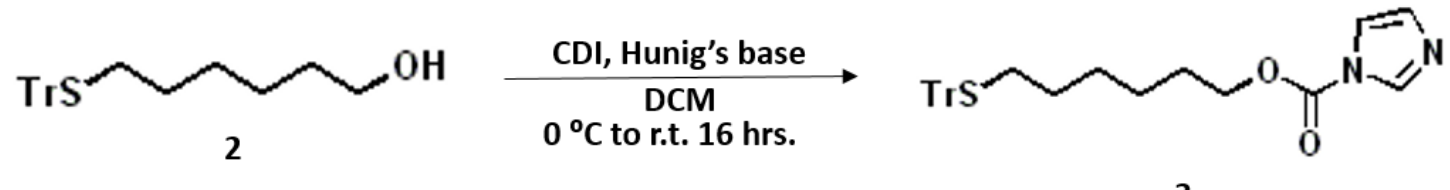

3

6-(Tritylthio)hexyl 1H-imidazole-1-carboxylate (3). 1,1'-carbonyldiimidazole (1.27 g, 7.86 mmol) was added to a solution of $\mathrm{N}, \mathrm{N}$-diisopropylethylamine $(1.02 \mathrm{~g}, 7.86 \mathrm{mmol})$ and 6(tritylthio)hexan-1-ol $(1.97 \mathrm{~g}, 5.24 \mathrm{mmol})$ in dichloromethane $(25 \mathrm{~mL})$ at $0{ }^{\circ} \mathrm{C}$. The reaction was stirred at room temperature overnight. The reaction mixture then was washed with water ( 25 $\mathrm{mL} \times 2)$ and extracted with dichloromethane ( $25 \mathrm{~mL})$. The organic layer was washed with saturated ammonium chloride $(25 \mathrm{~mL})$ and brine $(25 \mathrm{~mL})$, dried over anhydrous sodium sulfate, and concentrated by rotary evaporation to give $\mathbf{3}$ as a yellow oil which was used without further purification. Figure 16. IR v $\left(\mathrm{cm}^{-1}\right)$ 1761, 1486, 1441, 1237; Figure 21. ${ }^{1} \mathrm{H} \mathrm{NMR}(500 \mathrm{MHz}$, $\left.\mathrm{CDCl}_{3}\right): \delta 1.30(\mathrm{~m}, J=3 \mathrm{~Hz}, 4 \mathrm{H}), 1.40$ (pent, $\left.J=7 \mathrm{~Hz}, 2 \mathrm{H}\right), 1.70$ (pent, $\left.J=7 \mathrm{~Hz}, 2 \mathrm{H}\right), 2.16(\mathrm{t}, J=7 \mathrm{~Hz}$, $2 \mathrm{H}), 4.35(\mathrm{t}, J=6.5 \mathrm{~Hz}, 2 \mathrm{H}), 7.11(\mathrm{~s}, 1 \mathrm{H}), 7.20(\mathrm{t}, J=7.5 \mathrm{~Hz}, 3 \mathrm{H}), 7.27(\mathrm{t}, J=7 \mathrm{~Hz}, 6 \mathrm{H}), 7.41(\mathrm{~d}, J=$ $7.5 \mathrm{~Hz}, 6 \mathrm{H}), 8.11(\mathrm{~s}, 1 \mathrm{H}), 7.68(\mathrm{~s}, 1 \mathrm{H})$; Figure $\left.26 .{ }^{13} \mathrm{C} \mathrm{NMR} \mathrm{(400} \mathrm{MHz,} \mathrm{CDCl}_{3}\right): \delta 25.4,28.4,28.6$, 31.7, 31.9, 66.6, 68.4, 117.2, 126.7, 128.1, 129.7, 130.8, 137.2, 145.1, 148.9; HRMS m/z cald $\left[\mathrm{C}_{29} \mathrm{H}_{32} \mathrm{~N}_{2} \mathrm{O}_{2} \mathrm{~S}\right]^{+}$471.2101, observed 471.2096. 


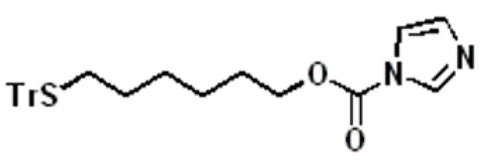

3

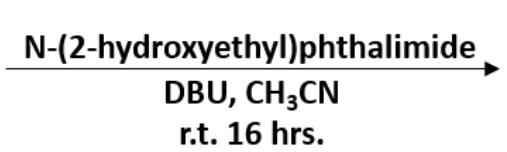

r.t. 16 hrs.

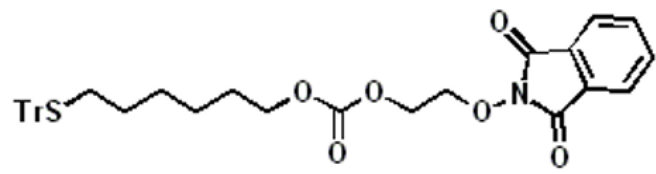

4

2-((6-(Tritylthio)hexyl)oxy)isoindoline-1,3-dione (4). N-(2-Hydroxyethyl)phthalimide (2.29 g,

$11.1 \mathrm{mmol}$ ) was added to a solution of 6-(tritylthio)hexyl $1 \mathrm{H}$-imidazole-1-carboxylate $(5.21 \mathrm{~g}$, $11.1 \mathrm{mmol})$ and 1,8-diazabicyclo[5.4.0]undec-7-ene (1.65 mL, $11.1 \mathrm{mmol})$ in acetonitrile $(50 \mathrm{~mL})$ at room temperature. The reaction was stirred overnight. The reaction was diluted with ethyl acetate and washed with saturated ammonium chloride $(25 \mathrm{~mL} \times 2)$. The layers were separated and the aqueous layer was extracted with ethyl acetate $(25 \mathrm{~mL} \times 3)$. The combined organic layer was washed with brine $(25 \mathrm{~mL})$, dried over anhydrous sodium sulfate, filtered, and concentrated by rotary evaporation to give a residue that was purified by column chromatography (hexane/ethyl acetate, 7:3) to afford a clear oil ( $4.48 \mathrm{~g}$, 66\% yield over 2

steps). Figure 17. IR $v\left(\mathrm{~cm}^{-1}\right)$ 1790, 1731, 1253; Figure 22. ${ }^{1} \mathrm{H} \mathrm{NMR}\left(500 \mathrm{MHz}, \mathrm{CDCl}_{3}\right): \delta 1.25$ (quint, $J=6.5 \mathrm{~Hz}, 4 \mathrm{H}$ ), 1.38 (pent, $J=7.0 \mathrm{~Hz}, 2 \mathrm{H}$ ), 1.55 (pent, $J=7.0 \mathrm{~Hz}, 2 \mathrm{H}$ ), $2.13(\mathrm{t}, J=7.5 \mathrm{~Hz}$, $2 \mathrm{H}), 4.08(\mathrm{t}, J=7.0 \mathrm{~Hz}, 2 \mathrm{H}), 4.46(\mathrm{~m}, J=4.0 \mathrm{~Hz}, 4 \mathrm{H}), 7.23(\mathrm{t}, J=7.0 \mathrm{~Hz}, 3 \mathrm{H}), 7.28(\mathrm{t}, J=7.0 \mathrm{~Hz}$, $6 \mathrm{H}), 7.40(\mathrm{~d}, J=8.0 \mathrm{~Hz}, 6 \mathrm{H}), 7.74(\mathrm{~m}, J=4.0 \mathrm{~Hz}, 2 \mathrm{H}), 7.83(\mathrm{~m}, J=3.0 \mathrm{~Hz}, 2 \mathrm{H})$; Figure $27 .{ }^{13} \mathrm{C}$ NMR $\left(400 \mathrm{MHz}, \mathrm{CDCl}_{3}\right): \delta 25.4,28.6,32.0,65.2,66.6,68.4,75.7,123.8,126.7,128.0,129.0,129.8$ $134.8,145.2,155.1,163.5$. 

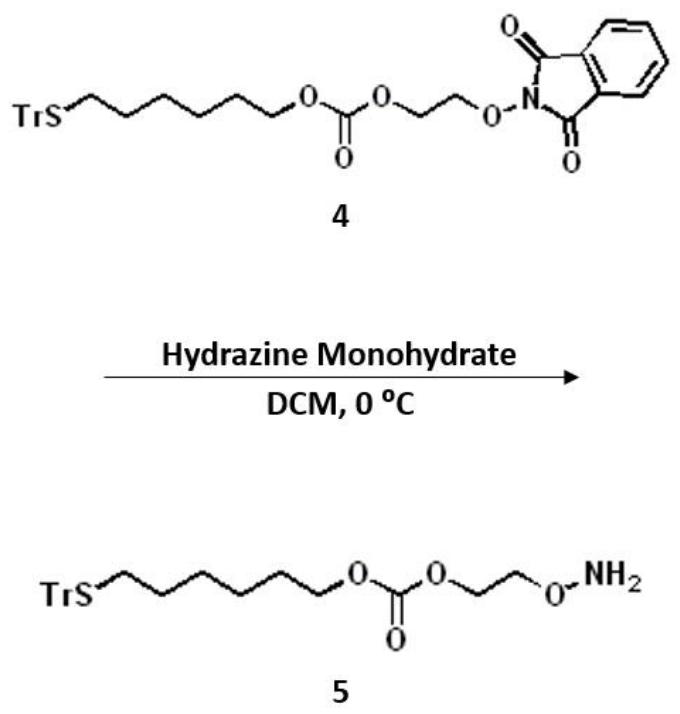

O-(6-(Tritylthio)hexyl)hydroxylamine (5). Hydrazine monohydrate $(2.16 \mathrm{~g}, 43.11 \mathrm{mmol})$ was added to a solution of $4(5.25 \mathrm{~g}, 8.62 \mathrm{mmol})$ in dichloromethane $(100 \mathrm{~mL})$ and stirred at $0{ }^{\circ} \mathrm{C}$ for 2 hours. The reaction was filtered and concentrated by rotary evaporation to give a colorless oil ( $4.06 \mathrm{~g}, 98 \%$ yield) which was used without further purification. Figure 18. IR v $\left(\mathrm{cm}^{-1}\right) 3322$, 1740, 1487, 1436, 1258, 1028; Figure 23. ${ }^{1} \mathrm{H}$ NMR $\left(500 \mathrm{MHz}, \mathrm{CDCl}_{3}\right): \delta 1.25(\mathrm{~m}, J=3.5 \mathrm{~Hz}, 4 \mathrm{H})$, 1.38 (pent, $J=7 \mathrm{~Hz}, 2 \mathrm{H}), 1.58$ (pent, $J=7 \mathrm{~Hz}, 2 \mathrm{H}), 2.14(\mathrm{t}, J=7 \mathrm{~Hz}, 2 \mathrm{H}), 3.86(\mathrm{t}, J=4 \mathrm{~Hz}, 2 \mathrm{H}), 4.07$ $(\mathrm{t}, J=6.5 \mathrm{~Hz}, 2 \mathrm{H}), 4.33(\mathrm{t}, J=4.5 \mathrm{~Hz}, 2 \mathrm{H}), 5.52(\mathrm{~s}, 1 \mathrm{H}), 7.20(\mathrm{t}, J=7 \mathrm{~Hz}, 3 \mathrm{H}), 7.27(\mathrm{t}, J=7 \mathrm{~Hz}, 6 \mathrm{H})$, $7.40(\mathrm{~d}, J=7.5 \mathrm{~Hz}, 6 \mathrm{H})$; Figure $28 .{ }^{13} \mathrm{C} \mathrm{NMR}\left(400 \mathrm{MHz}, \mathrm{CDCl}_{3}\right): \delta 25.4,28.5,28.6,28.7,31.9,65.4$, $66.6,68.2,73.4,126.7,127.9,129.8,145.2,155.6 ; \mathrm{HRMS} m / z$ cald $\left[\mathrm{C}_{28} \mathrm{H}_{34} \mathrm{NO}_{4} \mathrm{~S}\right]^{+} 480.2203$, observed 480.2206 . 

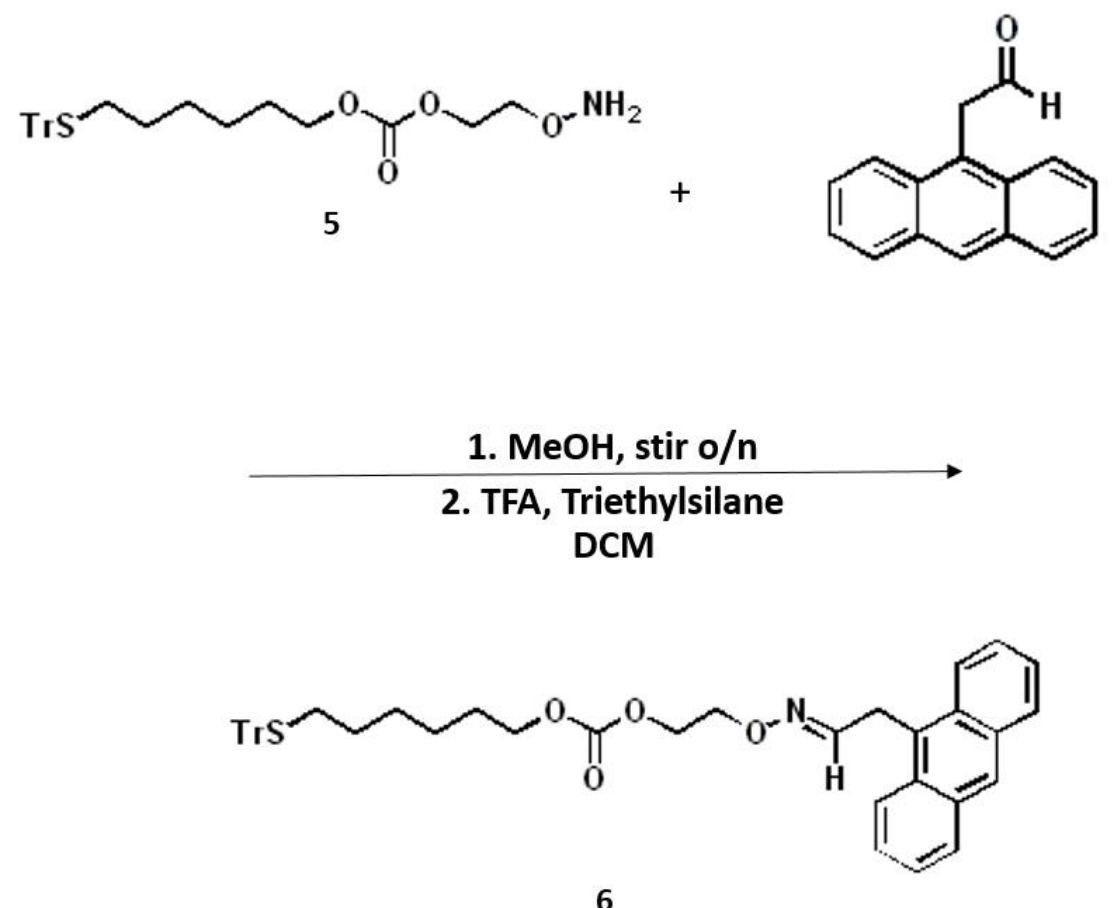

(E)-2-(((2-(anthracen-9-yl)ethylidene)amino)oxy)ethyl (6-(tritylthio)hexyl) carbonate (6).

Anthracene aldehyde $(0.494 \mathrm{~g}, 2.25 \mathrm{mmol})$ was added to $5(1.08 \mathrm{~g}, 2.25 \mathrm{mmol})$ in dichloromethane $(10 \mathrm{~mL})$ and stirred overnight. The solution was concentrated by rotary evaporation to give an orange oil and was used without further purification. Figure 19. IR v (cm $\left.{ }^{1}\right) 3290,1743,1664,1443,1488,1257$; Figure 24. ${ }^{1} \mathrm{H} \mathrm{NMR}\left(500 \mathrm{MHz}, \mathrm{CDCl}_{3}\right): \delta 1.24$ (d, J = 24.3 $\mathrm{Hz}, 4 \mathrm{H}), 1.34(\mathrm{t}, J=5.5 \mathrm{~Hz}, 2 \mathrm{H}), 1.52(\mathrm{t}, J=6.5 \mathrm{~Hz}, 2 \mathrm{H}), 2.11(\mathrm{t}, J=7.5 \mathrm{~Hz}, 2 \mathrm{H}), 4.03(\mathrm{t}, J=6 \mathrm{~Hz}$, $1 \mathrm{H}), 4.22(\mathrm{~s}, 1 \mathrm{H}), 4.50(\mathrm{t}, J=7.5 \mathrm{~Hz}, 2 \mathrm{H}), 6.73(\mathrm{~s}, 1 \mathrm{H}), 7.19(\mathrm{~d}, J=6 \mathrm{~Hz}, 3 \mathrm{H}), 7.25(\mathrm{t}, J=6.5 \mathrm{~Hz}, 7 \mathrm{H})$, $7.40(\mathrm{~d}, J=6 \mathrm{~Hz}, 6 \mathrm{H}), 7.46(\mathrm{t}, J=7 \mathrm{~Hz}, 2 \mathrm{H}), 7.99(\mathrm{~d}, J=8.5 \mathrm{~Hz}, 2 \mathrm{H}), 8.26(\mathrm{~d}, J=9.5 \mathrm{~Hz}, 1 \mathrm{H}), 8.38$ (s, 1H); Figure 29. ${ }^{13} \mathrm{C} \mathrm{NMR}\left(400 \mathrm{MHz}, \mathrm{CDCl}_{3}\right): \delta 25.2,28.5,31.8,66.0,66.5,68.0,71.2,123.9$, $125.1,126.6,127.2,127.9,129.7,130.2,131.5,149.4,150.5,155.2$.

\section{Loading the Linker System onto the Nanoparticles}


Trifluoroacetic acid $(1.1 \mathrm{mmol}, 11 \mathrm{~mL})$ was added to 6 in an ice bath. Triethylsilane $(3.3 \mathrm{mmol}$, $0.53 \mathrm{~mL}$ ) was added dropwise, and the solution was stirred for 30 minutes. The solution was concentrated via rotary evaporation and used without further purification or characterization. The resulting reaction mixture was added to the gold-coated iron oxide nanoparticles at a ratio of $0.01 \mathrm{mmol}: 1.0 \mathrm{mg}$, linker: nanoparticles, in chloroform as solvent and stirred overnight. The linker system was then precipitated with ethanol. The resulting solution was placed in a centrifuge at 10,000 rpm for 15 minutes. The supernatant was discarded and the product was dissolved in hexanes. Ethanol was added to, once again, precipitate the linker system before being centrifuged. This process was repeated 5 times. ${ }^{11}$ Both the synthesis of the gold-coated $\mathrm{Fe}_{3} \mathrm{O}_{4} \mathrm{NPs}$ and the loading process were developed by Sara Biladeau, a graduate student in the Chemistry Department at the University of Louisville with whom I collaborated.

\section{Testing the Control Linker System Using an Alternating Magnetic Field}

The control linker system was then subjected to an alternating magnetic field (AMF). The machine used was an Ambrell system model EasyHeat-LI. The sample was loaded into a $3 \mathrm{~mL}$ polystyrene cuvette and placed into the center of the coil (as shown in the picture below). 


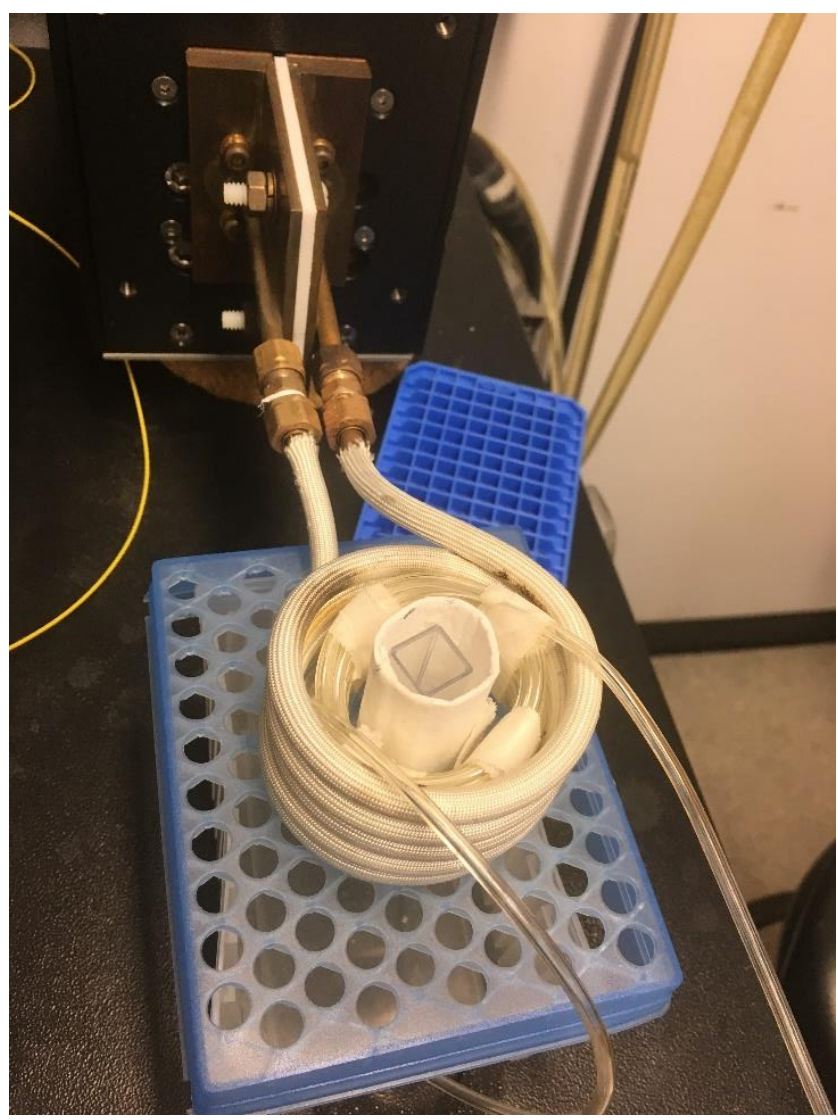

Figure 11. Setup of the AMF studies.

A narrow coil of tubing through which air flows was placed between the cuvette and the inner portion of the magnetic coil so as to reduce undesired heating of the bulk solution from the magnetic coil. The sample was then subjected to the AMF for a period of 15 minutes at $500 \mathrm{~A}$ and $204 \mathrm{kHz}$. These conditions were chosen so as to be comparable to Sara Biladeau's aminebased linker that also utilized anthracene as a payload. She noted that after 15 minutes under these conditions, maximum anthracene release was reached. With those results in hand, I decided to replicate the conditions used in her studies to compare results of both the aminebased and amine-deficient linker systems. 


\section{Analytical Analysis Using Matrix-assisted Laser Desorption/Ionization Time of Flight (MALDI-TOF)}

Analysis of the supernatant was performed on a Voyager DE-Pro MALDI-TOF instrument (PE

Biosystems). A sample solution was prepared for the instrument, and $0.5 \mu \mathrm{L}$ was used to spot

the wells of the MALDI plate and allowed to dry. Calibration was acquired by using known peaks from the 2,5-dihydroxybenzoic acid matrix. ${ }^{11}$ 


\section{Chapter 3}

\section{Part A: Results}

The results from the MALDI-TOF analysis of the supernatant from the AMF exposed linker system revealed that none of the payload had been released. The desired fragment, along with its mass, is shown below in Figure 12.

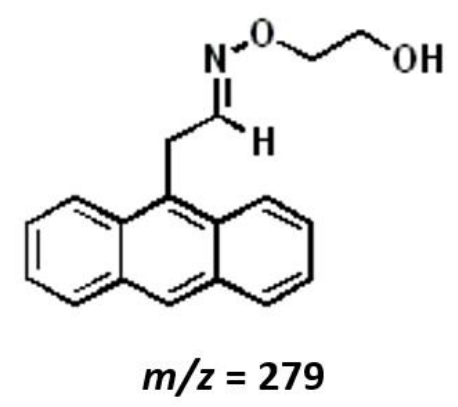

Figure 12. The alcohol fragment which indicates release of payload.

Special attention was placed on the area of the spectrum around the mass at $m / z=279$, the mass of the payload, had it been released. As can be seen from the below spectrum, no signal was detected near a mass at $m / z=279$, suggesting that the payload was not cleaved under the AMF exposure conditions studied. 


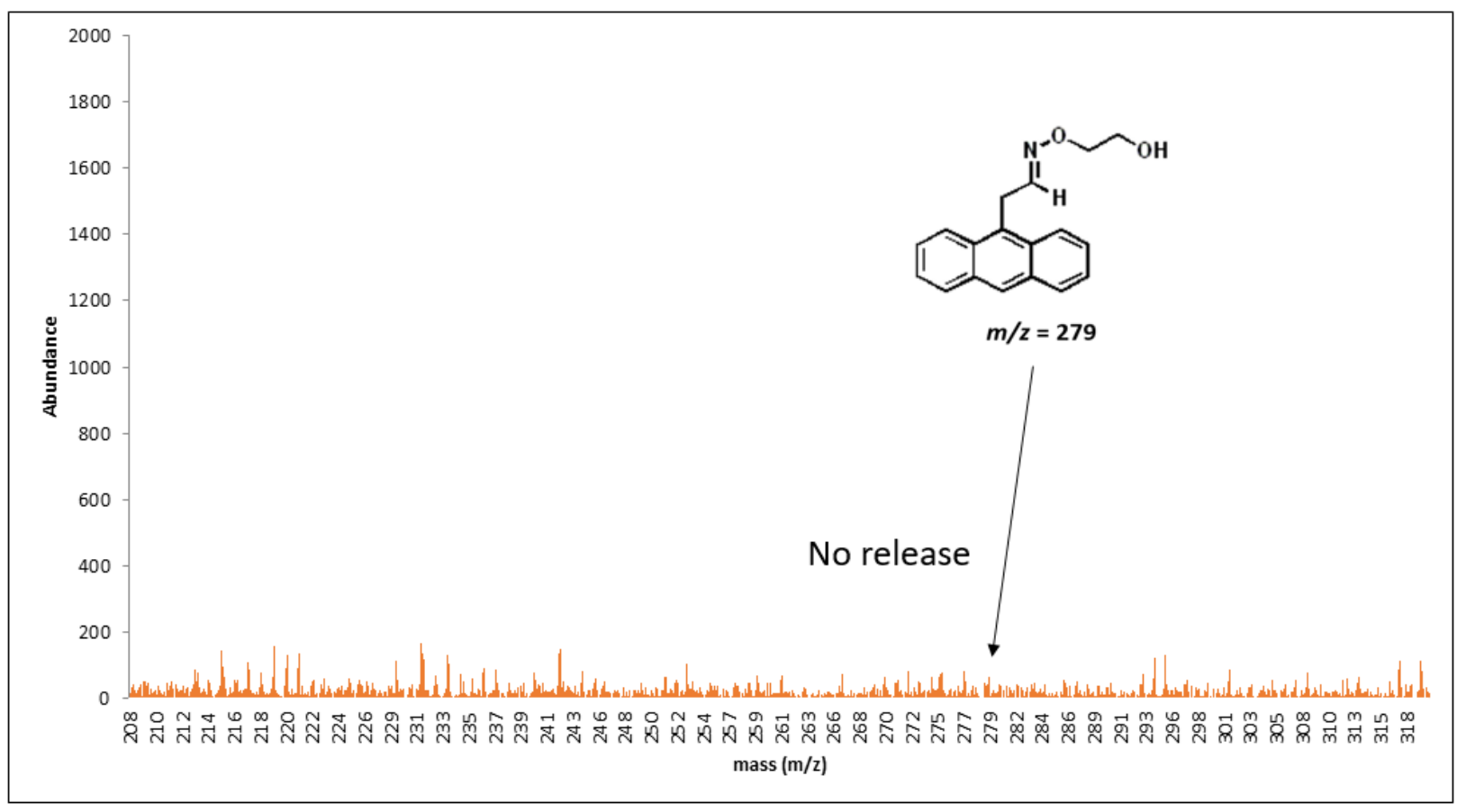

In contrast, when MALDI-TOF analysis was performed upon the supernatant of the linker system after it had been reduced by lithium aluminum hydride (LAH), the following spectrum was obtained.

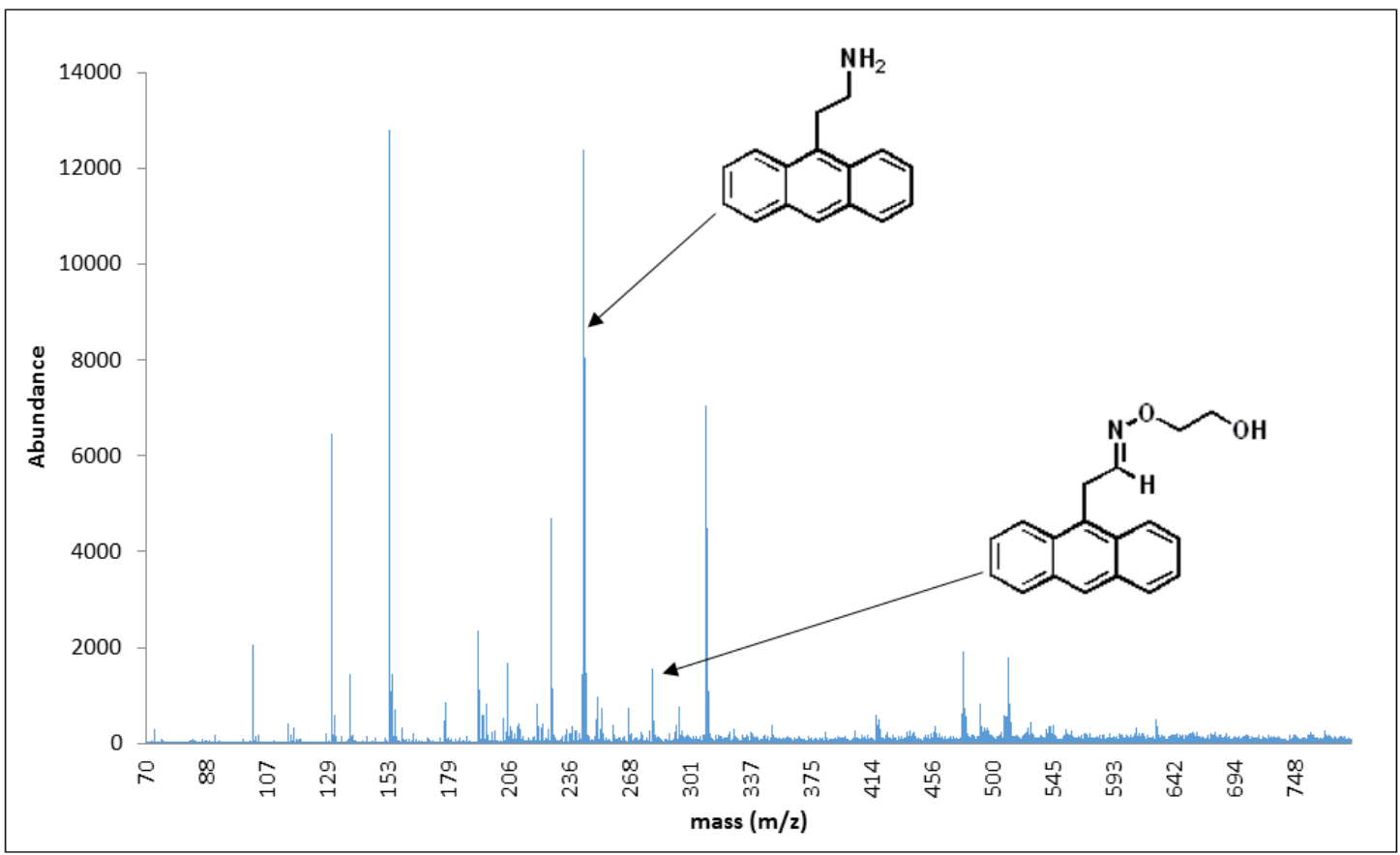


As can be seen in the figure, the signal at exactly $m / z=279$ reveals that the reduction had succeeded in cleaving the payload from the NP. However, some of the extra peaks in the spectrum cannot be identified as representative of the matrix solution used for MALDI-TOF. With a powerful reducing agent such as $\mathrm{LAH}$, it is possible that the extreme conditions could be the explanation for the extra peaks, as undesired by-products may have been formed in the process. One such product, the amine shown below, was observed in higher concentration than the expected oxime ether.

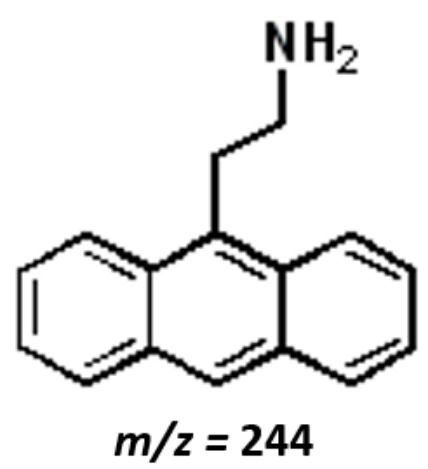

Figure 13. Oxime ether reduction product.

This product, the result of the complete reduction of the oxime ether to an amine, reveals the power of LAH as a reducing agent. Thus, while the desired peaks representing the payload were observed, the presence of unidentifiable peaks brings about much speculation. Therefore, a new approach implemented by Sara Biladeau on her amine-based system, was used to obtain clearer results. This approach includes using dithiothreitol (DTT) to cleave the gold-thiol bond thus removing the entire linker system from the gold-coated iron oxide NPs. Performing a DTT reduction is a much milder approach than the LAH reduction. MALDI-TOF analysis of the supernatant of this method is shown in the spectrum below. 


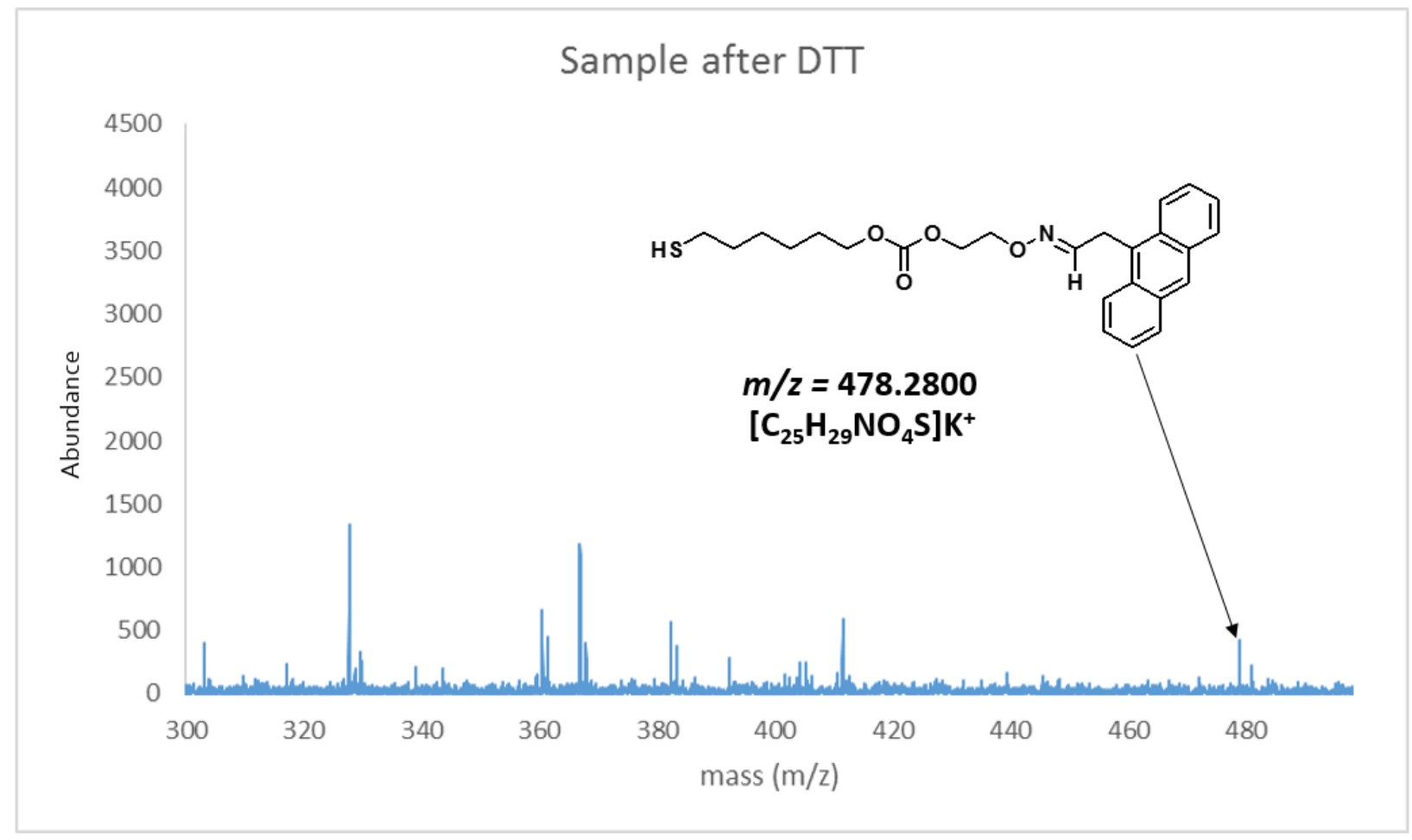

Analysis of this spectrum revealed the desired peak at $m / z=478$, indicative of the potassiated form of the entire linker system. All other signals can be attributed to the matrix used to run the sample. This evidence reveals that the payload had been successfully loaded onto the NPs 


\section{Part B: Conclusion}

The MALDI-TOF results suggest that the control non-nucleophilic linker system did not release the fluorophore payload upon exposure to an AMF. This was evidenced by the lack of a mass signal at $m / z=279$ corresponding to the fragment expected on reaction of the carbonate cleavage. While promising, this negative result is not sufficient by itself to confidently say that the payload did not release. With that in mind, we set out to establish that the fluorophore was still attached after AMF treatment. The linker system was subjected to the powerful reducing agent $\mathrm{LAH}$ to reduce the carbonate group so as to release the fluorophore. Analysis of the organic soluble fraction after reduction revealed two things: 1.) the anthracene payload was now detected by MALDI-TOF at the expected mass $\mathrm{m} / \mathrm{z}=279$ and as an amine at the mass $\mathrm{m} / \mathrm{z}$ = 244; and 2.) the linker system did indeed still contain the payload. However, as mentioned earlier, this method may not have been an ideal one; therefore, further studies with DTT as a milder reducing agent which facilitated the cleavage of the gold-thiol bond to release the entire linker system were performed to provide more definitive evidence. Thus, without the presence of the nucleophilic amine, intramolecular cyclization was prevented, resulting in retention of the payload. When the linker system was treated with hydride to cleave the carbonate, the payload was observed. As predicted in the hypothesis of this experiment, it can be confidently stated that the non-nucleophilic linker system does not significantly release the payload upon exposure to the AMF due to its lack of a nucleophilic element.

The work performed so far by Sara Biladeau and her linker system with a nucleophilic element (amine) ${ }^{11}$ has shown promising results. With a foresight of medical applications, she 
utilized a water soluble fluorophore, FITC, as a payload. This allows for testing to be performed under conditions that can be extremely similar to the human body's own internal chemical environment.

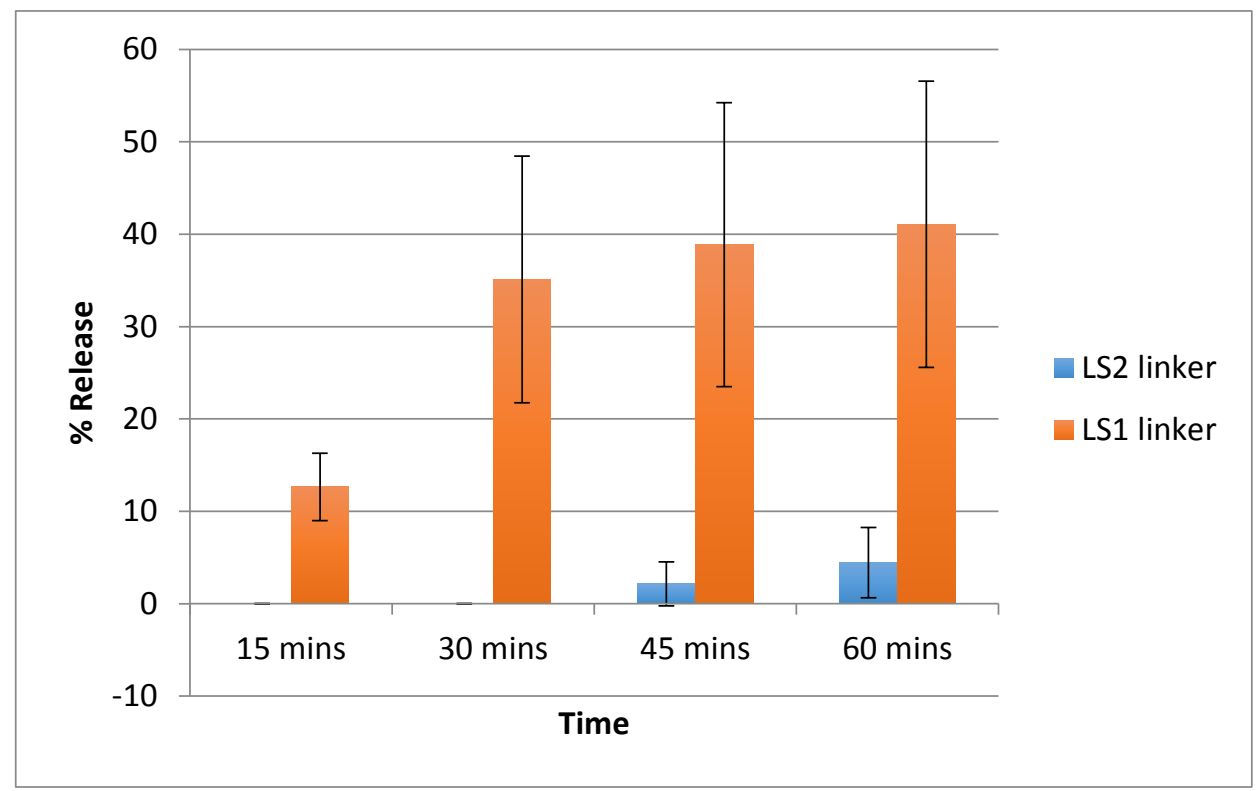

Figure 14. Graphical representation of the percent release of the amine-based linker system vs. the amine-deficient linker system. LS1 = amine-based linker system; LS2 = amine-deficient linker system. ${ }^{11}$

As can be observed from Figure 14, the amine-based linker system shows significant release of its payload when subjected to an AMF while the amine-deficient linker system does not show significant release of its payload. ${ }^{11}$

Proving the concept that the presence of an amine is responsible for payload release from this linker system has an impact which reaches beyond the laboratory. If the payload were to be a potent drug, such as the cancer drug Doxorubicin, this linker system would have the potential to more precisely deliver this highly toxic chemotherapeutic agent. Loading the linker 
system with a "cocktail" of drugs also could pave the path for personalized treatment plans in the medical community. 


\section{Reference List}

1. Bryan, Cyril (1932). The Ebers Papyrus. New York: D. Appleton and Company.

2. Aryal, S.; Grailer, J.; Pilla, S.; Steeber, D.; Gong, S. J. Mater. Chem. 2009, 19, 7879-7884.

3. Results Unpublished. (Knipp, R. J., Triggered Release of Small Molecules from Solid Supports Using Heating or an Applied Magnetic Field. Ph.D. Dissertation, University of Louisville, Louisville, KY, 2014.)

4. R.E. Rosensweig. Journal of Magnetism and Magnetic Materials 252:370-374, 2002.

5. Khan, A. K.; Rashid, R.; Murtaza, G.; Zahra, A. Trop. J. Pharm. Res. 2014, 13, 1169-1177.

6. Zandberg, W.; Bakhtiari, A.; Erno, Z.; Hsiao, D.; Gates, B.; Claydon, T.; Branda, N. Nanomedicine. 2012, 8, 908-915.

7. Zhao, J.; Wallace, M.; Melancon, M. P. Nanomedicine. 2014, 9, 2041-2057.

8. Guo, Y.; Zhang, Z.; Kim, D.-H.; Li, W.; Nicolai, J.; Procissi, D.; Huan, Y.; Han, G.; Omary, R.; Larson, A.C. Int. J. Nanomed. 2013, 8, 3437-3446.

9. Mohammad, F.; Yusof, N. J. Colloid Interface Sci. 2014, 434, 89-97.

10. Bain, Colin D., et al. "Formation of monolayer films by the spontaneous assembly of organic thiols from solution onto gold." Journal of the American Chemical Society 111.1 (1989): 321-335.

11. Results Unpublished. (Biladeau, Sara. Untitled. Ph.D. Dissertation, University of Louisville, Louisville, KY, 2017.) 
Chapter 4

Supporting Information 


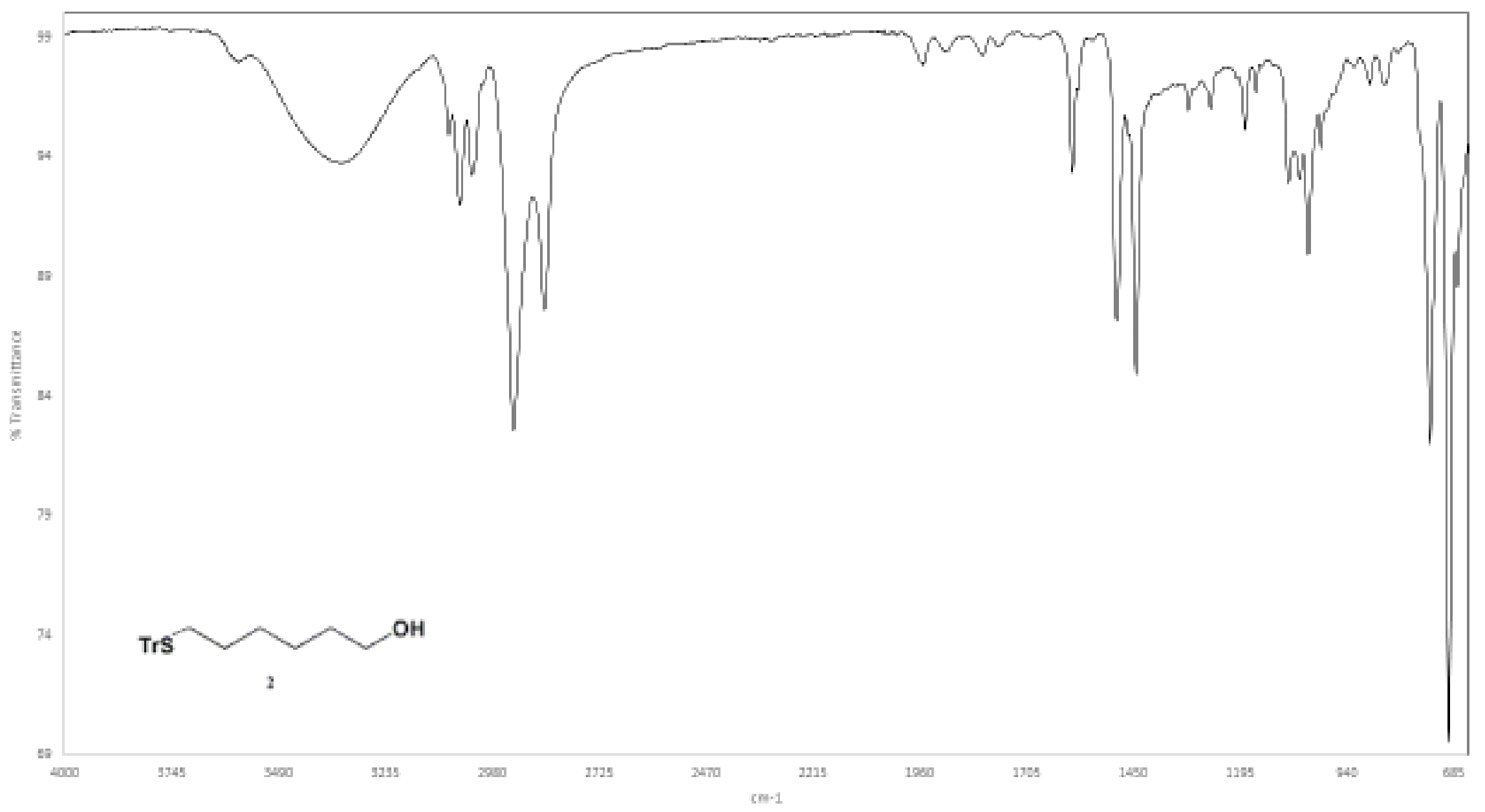

Figure 15: IR spectrum of product 2.

31 


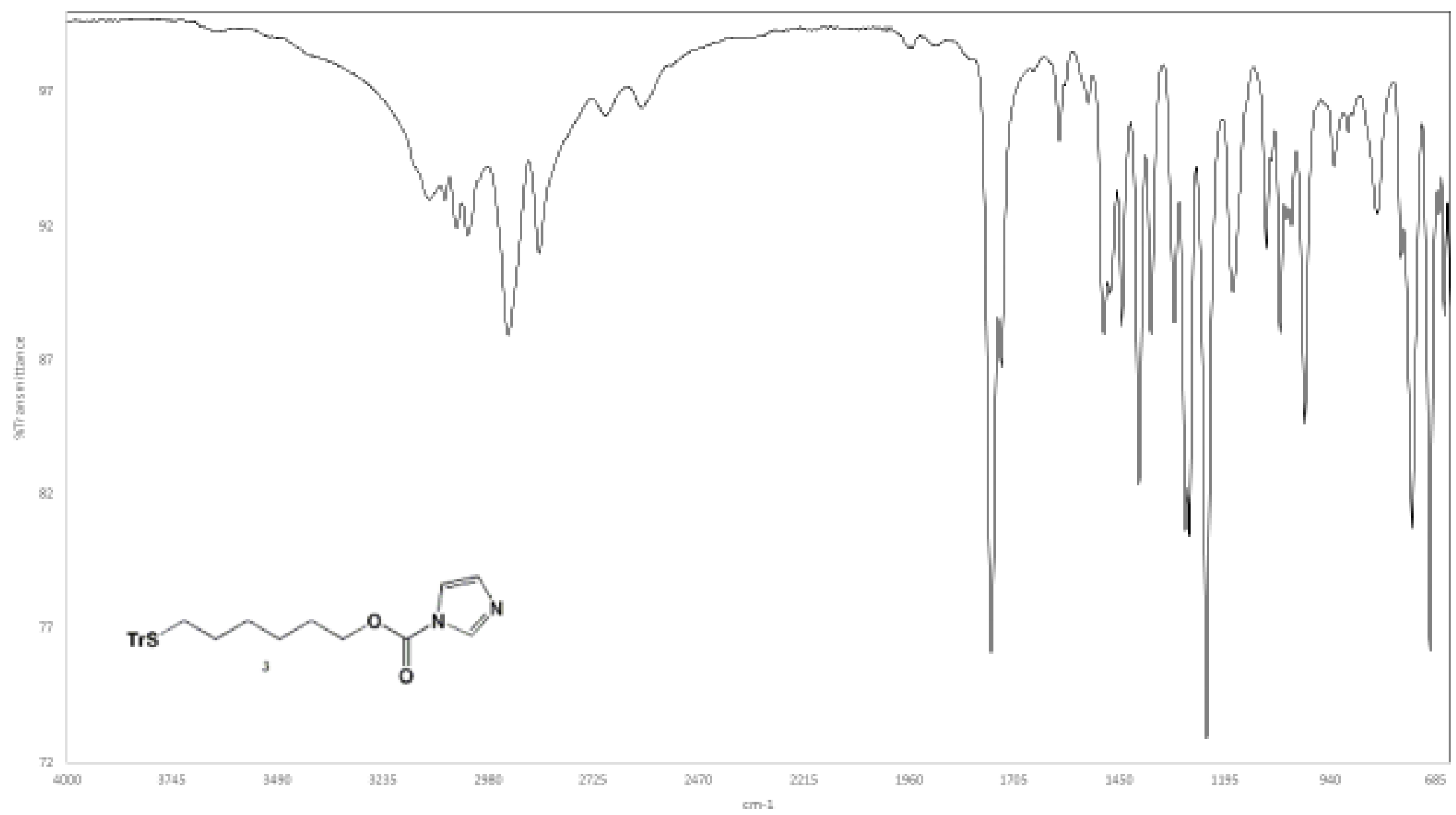

Figure 16: IR spectrum of product 3. 


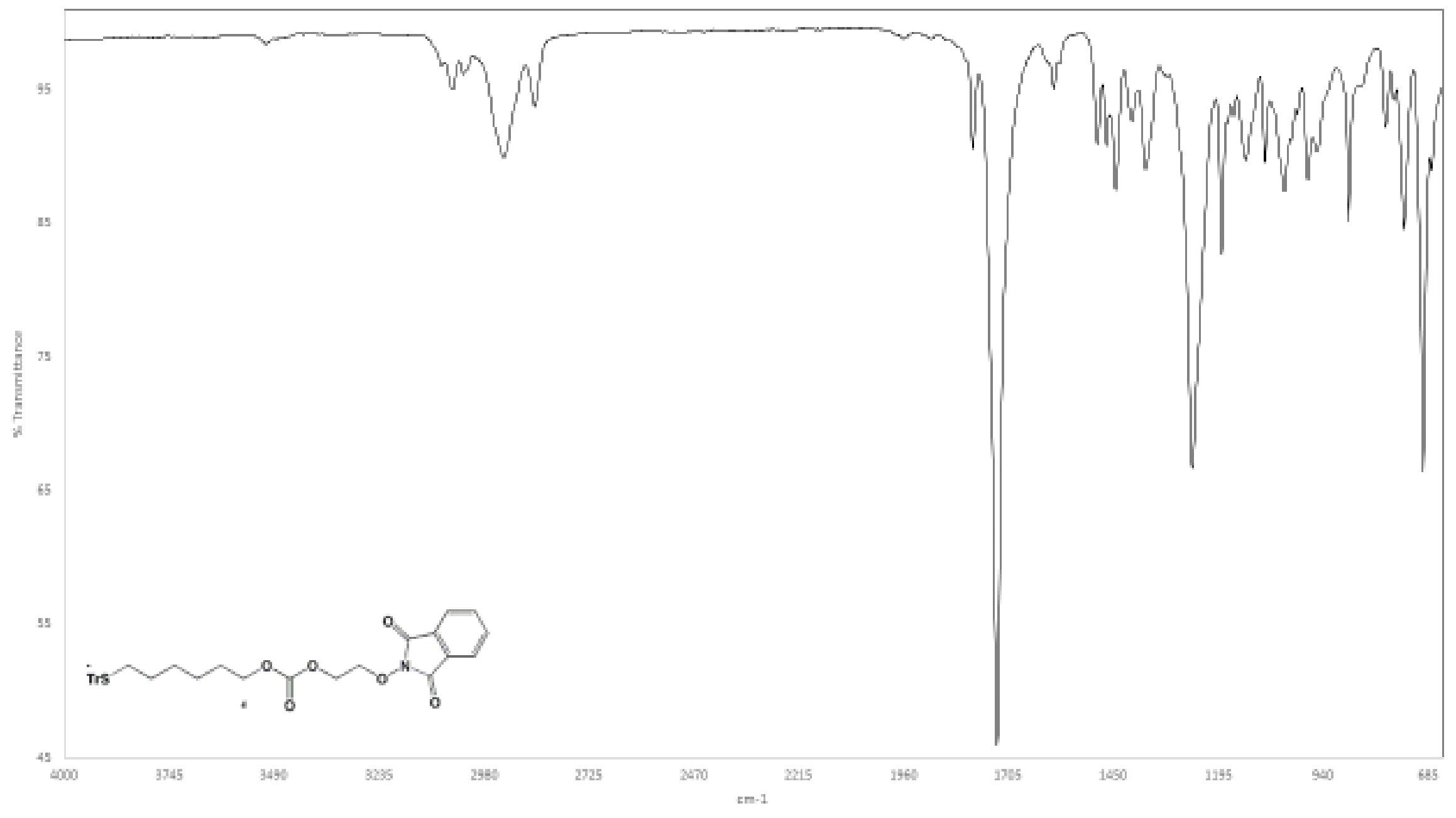

Figure 17: IR Spectrum of product 4. 


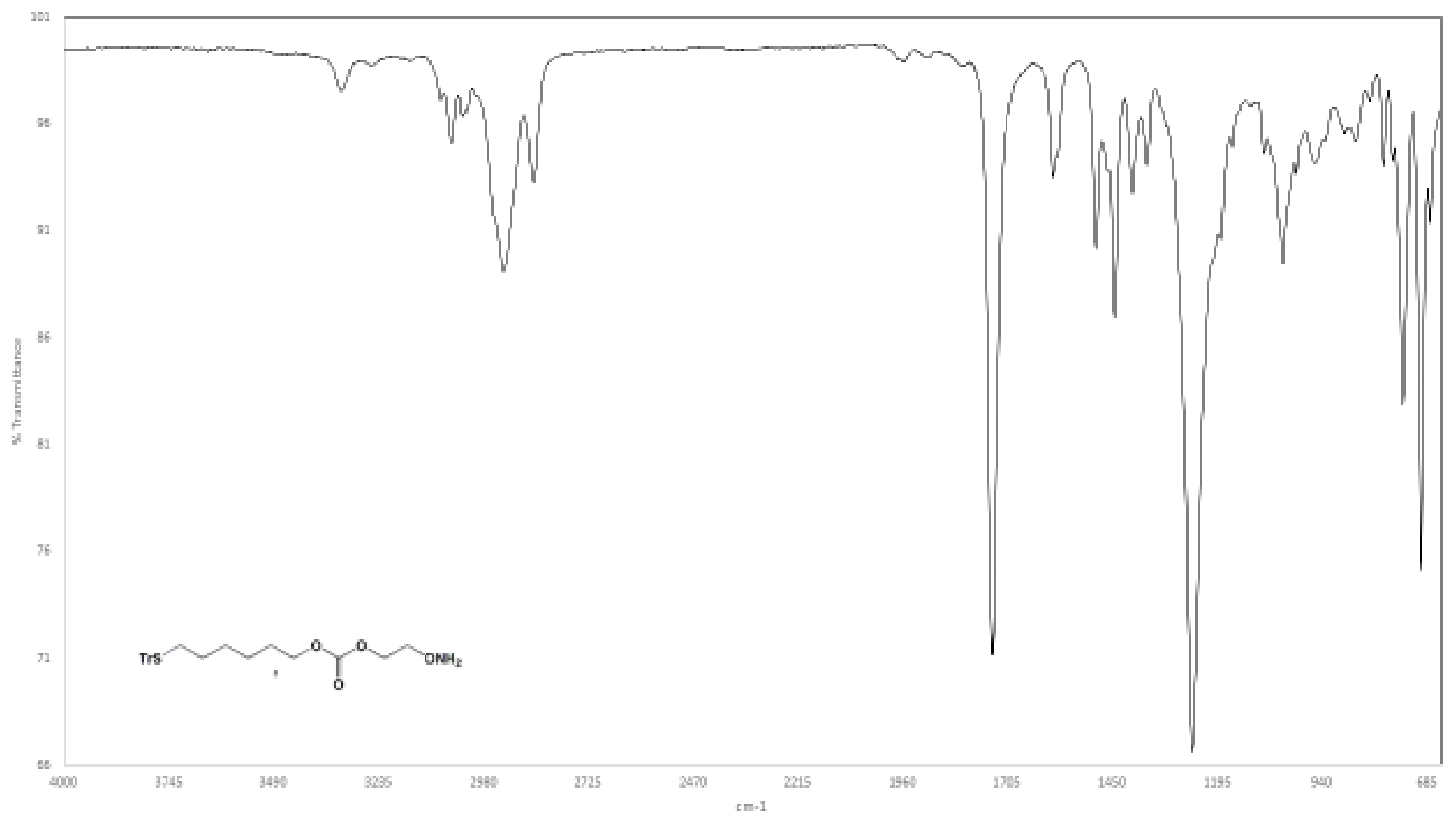

Figure 18: IR spectrum of product 5.

34 


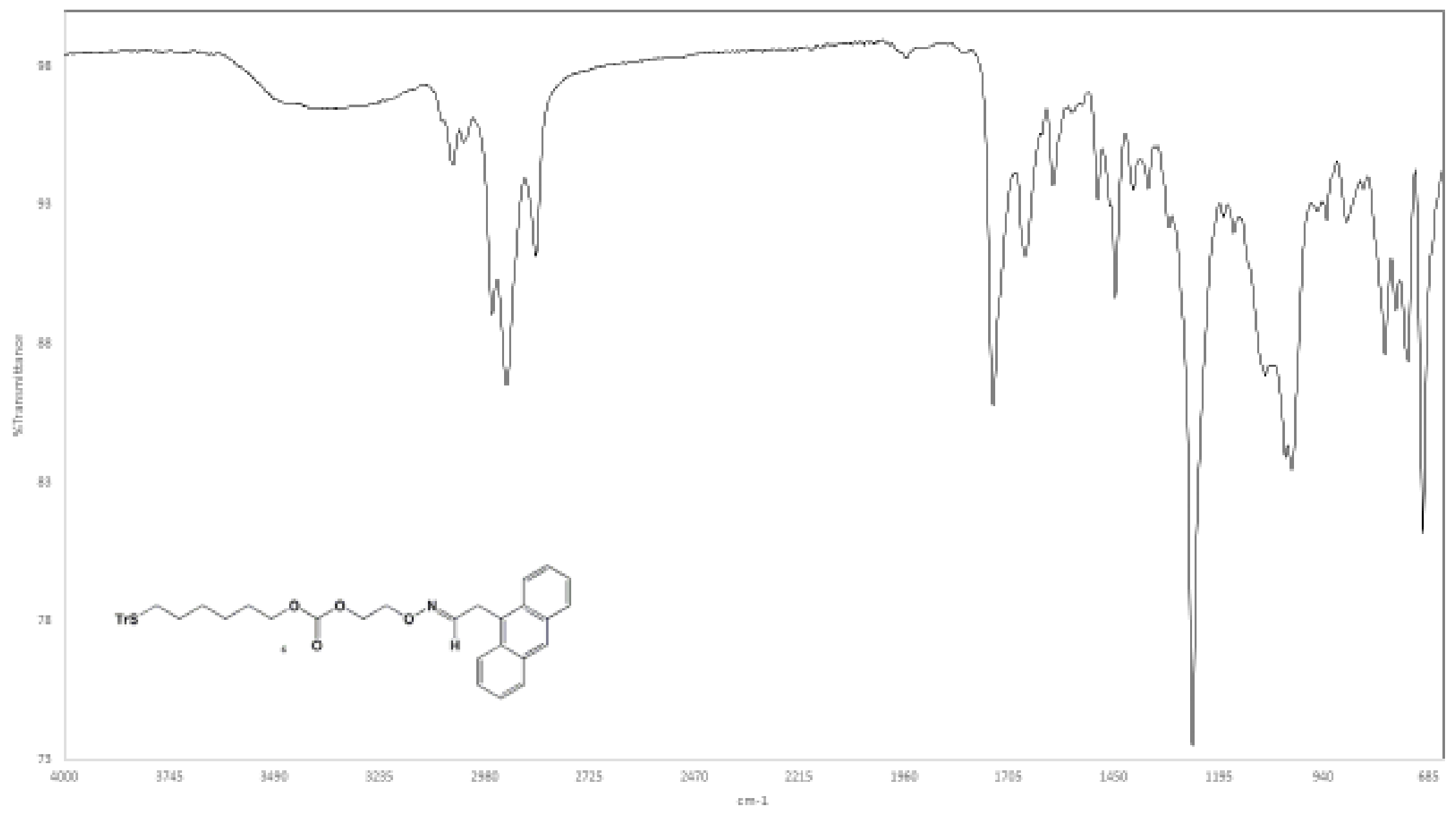

Figure 19: IR spectrum of product 6 . 
SKB-VI-71_H_2

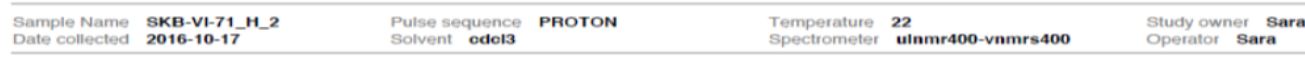

SKB-V1-71_H_2

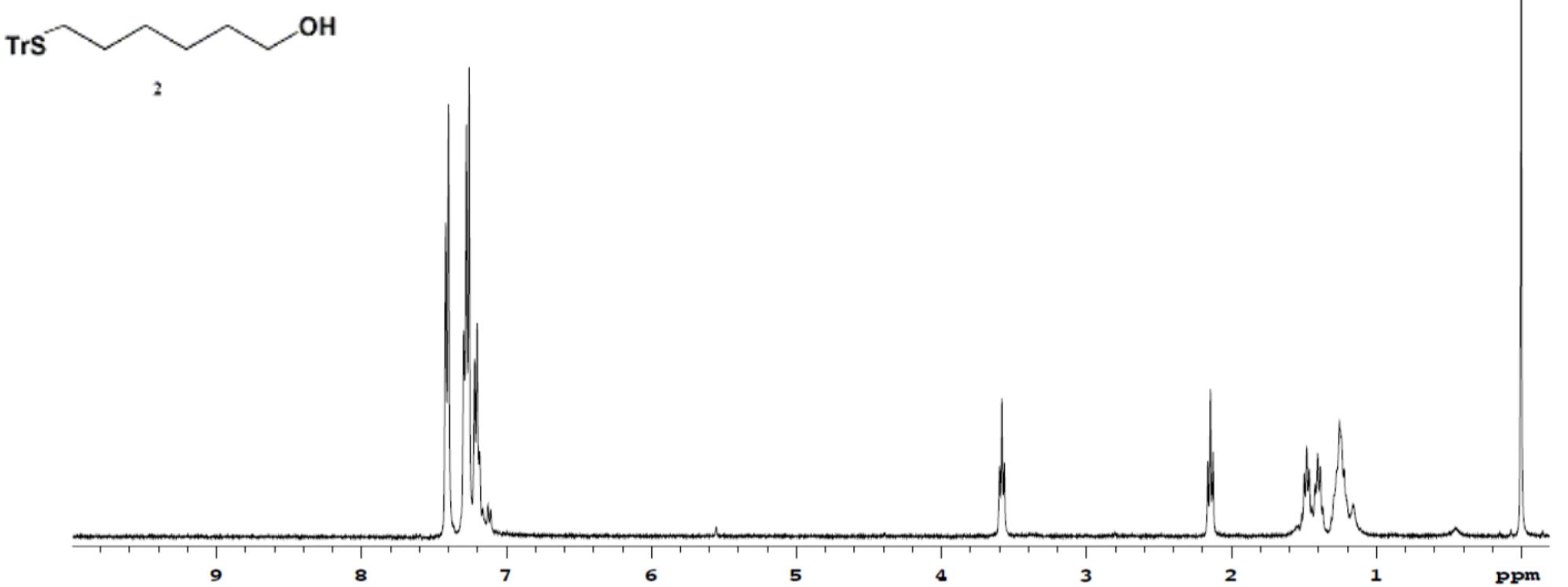

Plotname: skb-vi-71

Data flle /home/walkupNnmrsys/data/Sara/SKB-V1-71_H_2 20161017_01/PPOTON 01 fid

Figure 20: ${ }^{1} \mathrm{H}$ NMR spectrum of product 2. 
SKB-VI-73_H_2

SKB-VI-73_H_2<smiles>O=C(OCCCCCCS)n1ccnc1</smiles>

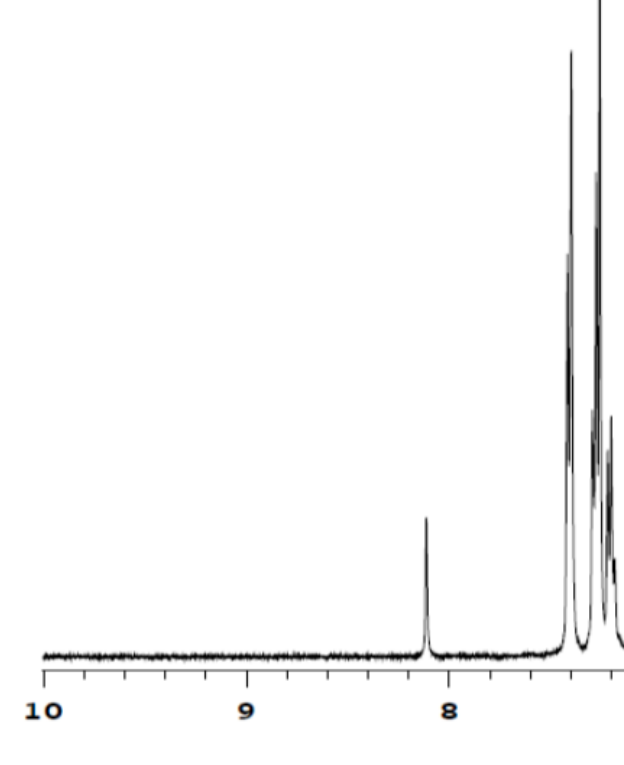

Plotname: skb-vi-73_h

Figure 21: ${ }^{1} \mathrm{H}$ NMR spectrum of product 3. 
SKB-V1-26_H
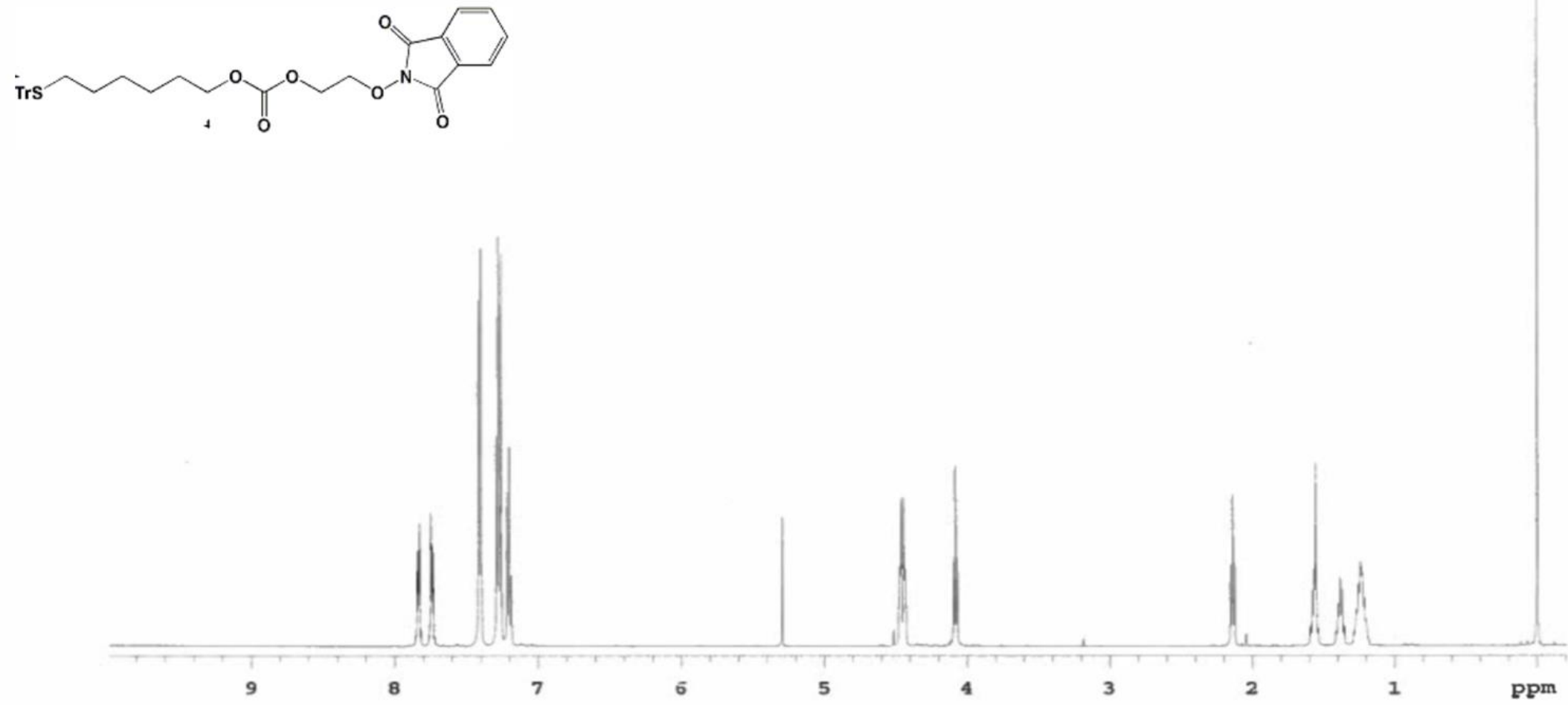

Figure 22: ${ }^{1} \mathrm{H}$ NMR spectrum of product 4 . 


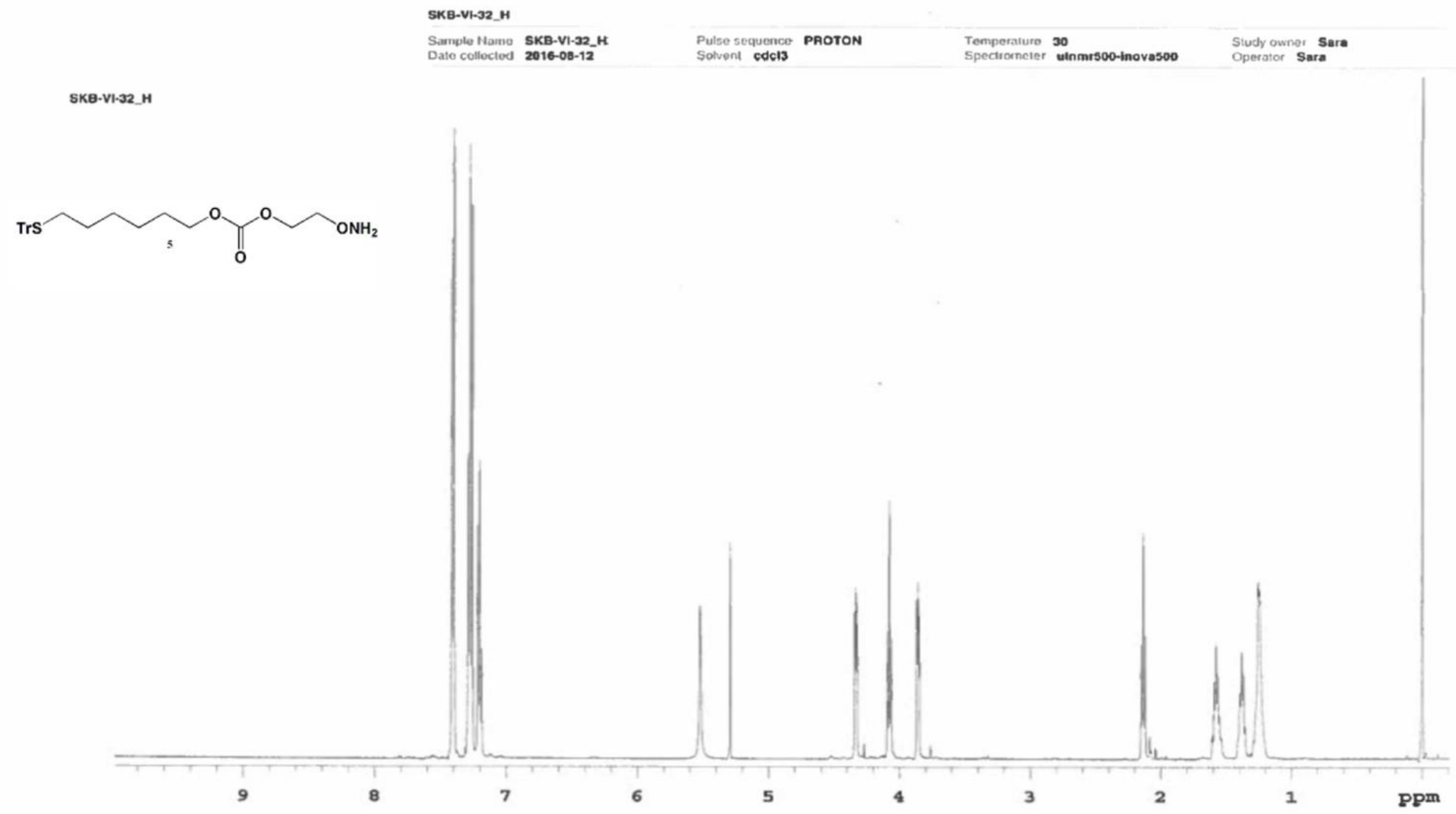

Figure 23: ${ }^{1} \mathrm{H}$ NMR spectrum of product 5. 
SKB-V1-46_H

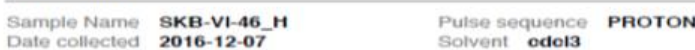

TrS
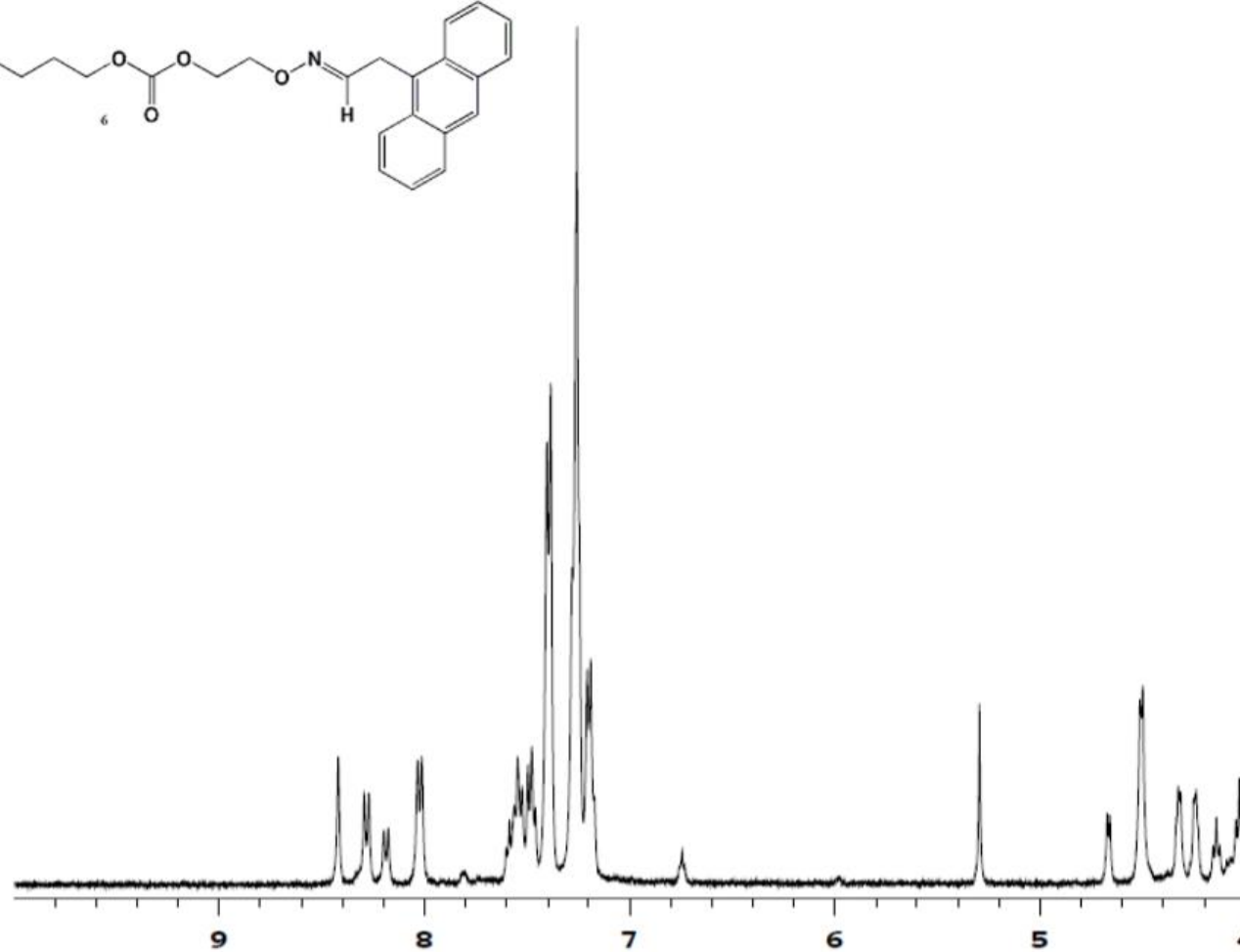

(1)

Plotname: skb-vi-46_h

Figure 24: ${ }^{1} \mathrm{H}$ NMR spectrum of product 6. 


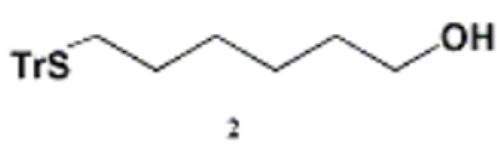

2

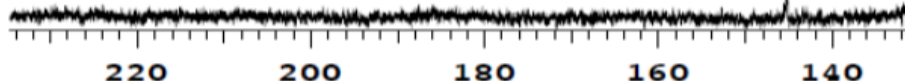

Plotname: rw-i-74_h

Figure 25: ${ }^{13} \mathrm{C}$ NMR spectrum of product 2 . 
<smiles>O=C(OCCCCCCS)n1ccnc1</smiles>

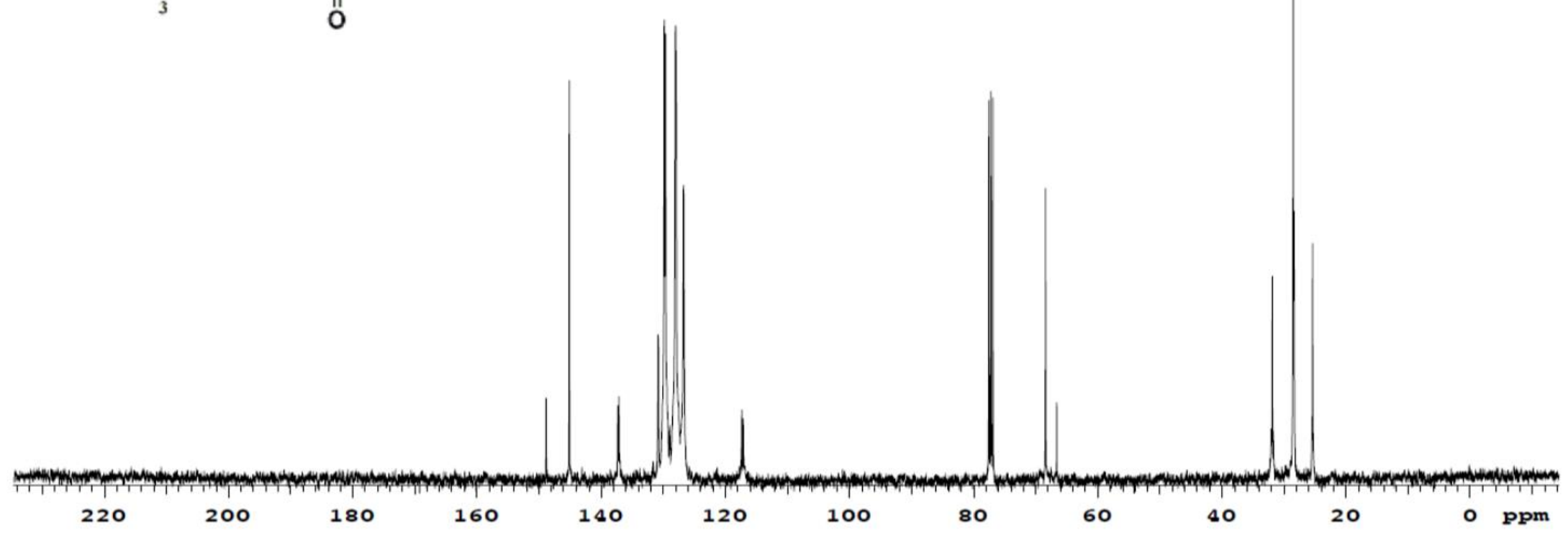

Plotname: Skb-vi-73_c

Figure 26: ${ }^{13} \mathrm{C}$ NMR spectrum of product 3. 
SKB-VI-26_C

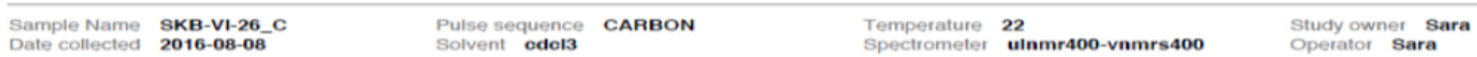

SKB-VI-26_C
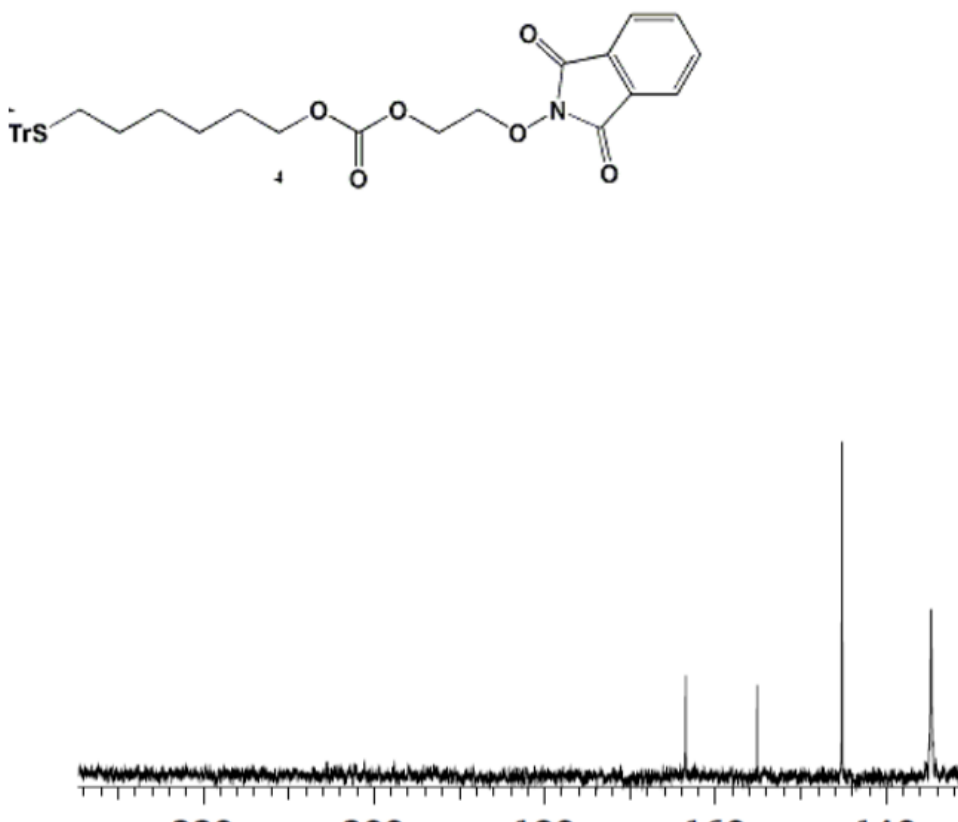

220

200

180

160

140

120

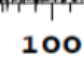

100

80

Plotname: skb-vi-26

Figure 27: ${ }^{13} \mathrm{C}$ NMR spectrum of product 4. 

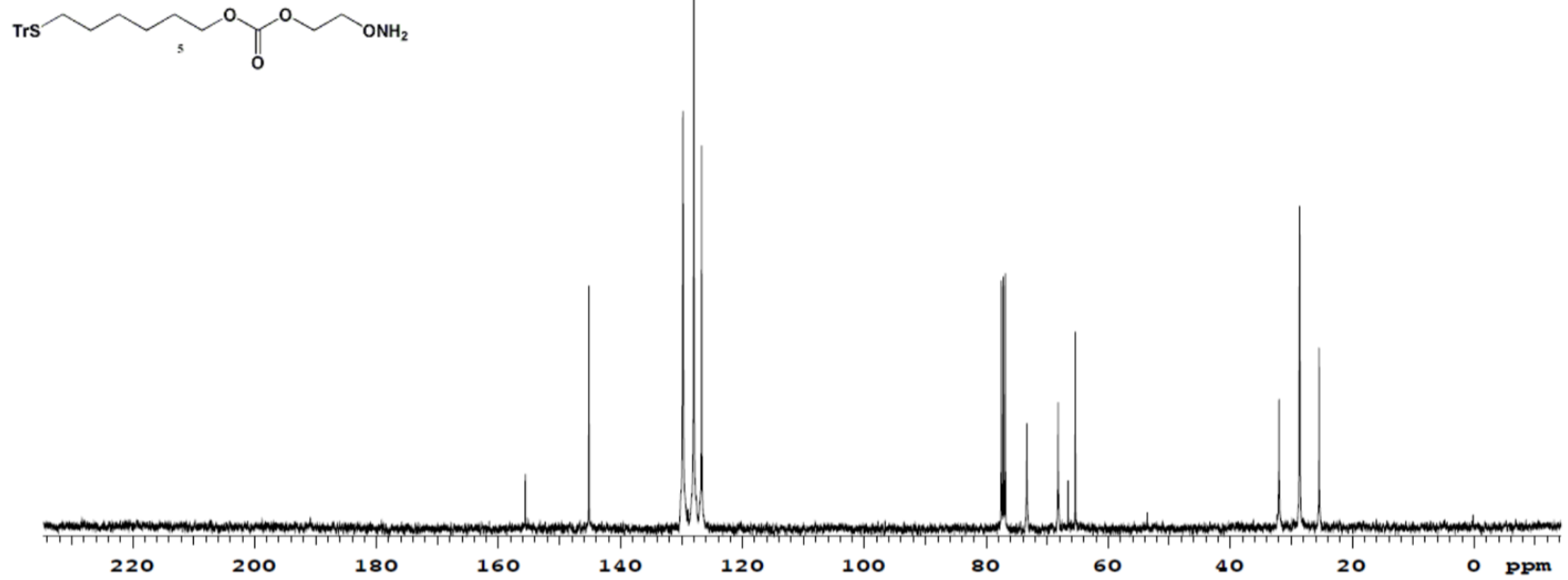

Plotname: rw-i-76_e

Figure 28: ${ }^{13} \mathrm{C}$ NMR spectrum of product 5. 
SKB-v1-46_C

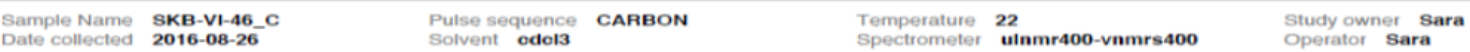

SKB-VI-46_C

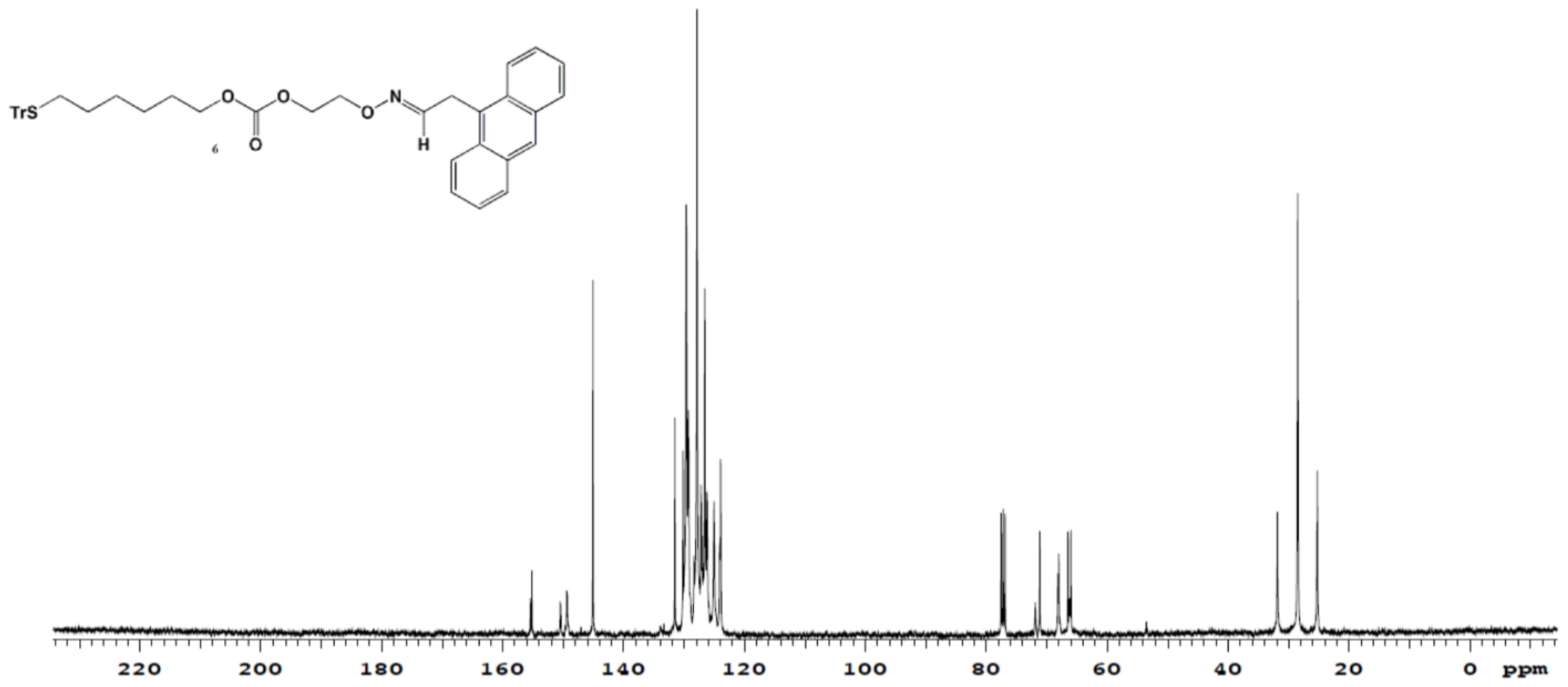

Plotname: skb-vi-46_c

Figure 29: ${ }^{13} \mathrm{C}$ NMR spectrum of product 6 . 
